\title{
The Influence of IT Investment on Business Performance: A Comparative Study of Regression Analysis and Artificial Neural Networks
}

\author{
Shin-Yuan Hung \\ National Chung Cheng University \\ Chia-Yi, Taiwan, R.O.C. \\ syhung@mis.ccu.edu.tw \\ Ya-Han Hu \\ National Chung Cheng University \\ Chia-Yi, Taiwan, R.O.C. \\ yahan.hu@mis.ccu.edu.tw \\ Chin-S Ou \\ National Chung Cheng University \\ Chia-Yi, Taiwan, R.O.C. \\ actcso@ccu.edu.tw \\ Kuanchin Chen \\ Western Michigan University \\ Kalamazoo, Michigan, 49008-5412 USA \\ kc.chen@wmich.edu \\ Chun-Chuan Lu \\ National Chung Cheng University \\ Chia-Yi, Taiwan, R.O.C. \\ axlu@mis.ccu.edu.tw
}

\begin{abstract}
Due to the considerable advances and tangible benefits of information technology (IT), almost all top-tier firms invest heavily in IT applications. However, the phenomenon of the "IT productivity paradox" prevents firms from investing in IT freely. Despite the number of studies exploring the relationship between IT investment and business performance, the value of IT investment remains difficult to justify. Specifically, evidence of a payoff from massive IT investments is still very limited. Added to the complexity is a wide range of key performance indicators that target different aspects of business performance. According to previous studies, the reasons behind the IT productivity paradox may be a shortage of accurate and timely data, a failure of considering the time-lag effect, and the application of inappropriate data analysis techniques. To address the aforementioned symptoms, this study developed a system to examine the influence of IT investment on two categories of performance indicators, namely cost efficiency and profit effectiveness. Specifically, we collected actual enterprise operating data, applied two different data analysis techniques (i.e., regression analysis and artificial neural networks), and conducted analysis using data collected over a period of four years. The results indicate that: (1) the higher the ratio of maintenance costs, the poorer business performance will be; (2) the higher the ratio of IT investment, the better the business performance and the lower the operating cost will be; (3) we also found that the time lag effects of IT investment on business performance for a period of two to three years; (4) regarding the estimation of the influence of IT investment on business performance, artificial neural networks are superior to regression analysis for their explanatory power.
\end{abstract}

Keywords: IT Investment, Business Performance, Artificial Neural Networks, Regression Analysis 
The Influence of IT Investment on Business Performance/ Hung. et al.

\section{Introduction}

In recent decades, information technology (IT) investment has been increasing tremendously. Many firms believe that IT investment not only enhances IT capability, but also reduces operating costs (Girma et al., 2001; Kim et al., 2009; King and Grover, 1991; Kohli and Devaraj, 2004; Ong and Chen, 2013; Ravichandran et al., 2005; Ravichandran et al., 2009; Thouin et al., 2009). For these reasons, firms have begun investing heavily in IT applications in order to enhance their organizational performances (Dale Stoel and Muhanna, 2009; Robson, 1997; Rumelhart et al., 1986; Weill et al., 1996). Although many prior studies have examined the relationship between IT investment and business performance, evidence of the payoffs from massive IT investment is rather limited (Devaraj and Kohli, 2003; Hung et al., 2012; Huang et al., 2006; Liang et al., 2010; Lim et al., 2011; Osei-Bryson and Ko, 2004; Santhanam and Hartono, 2003; Weill, 1992; Weill and Olson, 1989).

Since the 1980s, a number of scholars have disputed the relationship between IT investment and productivity from the angle of national economics, as well as the viewpoints of individual organizations and industries. A recent example that looks at IT investment at the macroeconomic level includes Eid (2010), where he divided IT investment into three time frames: 1959-1980, 1981-2008, and 1994-2008. IT investment had a key impact on productivity between 1959 and 1980, but its impact on productivity was mixed from 1981-2008 (a finding that conflicts with Stiroh (2001)).

Furthermore, a number of researchers believe that an over-investment in IT is one of the reasons for the phenomenon of "productivity slow down" occurring in the United States since 1973 (Roach, 1988; Strassmann, 1990). Some have presented a similar argument. For example, Ho and Mallick (2009) found that the effect of IT investment on profitability in the banking industry might be negligible because of the pressures from rival banks. However, if it is coupled with a variety of bundled deals, the effect is less likely to be copied and therefore more sustainable in the long run.

Others have insisted that IT is a critical factor in gaining a competitive edge (Cash and Konsynski, 1985; Grant, 1991; Mata et al., 1995; Matusik and Hill, 1998; McFarlane, 1984; Porter and Millar, 1985; Ross et al., 1996). There is also evidence of such a positive relationship between IT investment and firm performance outside of the U.S. (Ali Bazaee, 2010).

In the 1990s, the phenomenon of the "IT productivity paradox" attracted the attention of many researchers in the fields of economics, management sciences, and information systems. Many scholars collected enterprise data and employed a variety of analytical techniques to examine the relationship between IT investment and business performance (Bresnahan et al., 2002; Brynjolfsson, 1993; Brynjolfsson and Hitt, 1996; Brynjolfsson and Hitt, 1998; Brynjolfsson and Hitt, 1993; Jorgenson and Stiroh, 1999; Jorgenson and Stiroh, 2000; Oliner and Sichel, 2000). Many researchers support the contention that IT has a considerable, positive impact on productivity.

Although a number of previous studies have attempted to explore the relationship between IT investment and business performance to confirm that IT has a positive impact on productivity, the value of IT investment remains difficult to justify, particularly monetarily (Chang et al., 2008). The reasons for this may be that most previous studies have focused on conceptual discussions, case studies, or statistical methods (Chi and Tang, 2005). Such studies rely heavily on questionnaires and interviews, which constitute the perceptual aspect of the story. Often times, perceptions and what the real operating data reveal may not be in perfect synchronization due to the multiple sources that could steer perceptions in different directions. Therefore, insights drawn from opinion surveys can be enhanced through a careful examination of operating data that captures realistic business activities. 
Even when real data was collected, many times a non-existent (or weak) relationship was found between IT investment and firm performance. Brynjolfsson (1993) suggests that this could have been due to the issue of the time lag. When a firm invests in IT, it usually does not see the beneft of it until later. The time lag could be two to three years according to Brynjolfsson (1993).

Added to the complexity of predicting or modeling firm performance is that the analytical techniques are not created equal. Recent studies have shown that, in prediction applications, data mining or machine learning techniques are superior to conventional statistical methods (Sabzevari et al., 2007; Zurada and Lonial, 2005). The use of machine learning techniques in conjunction with accurate and timely IT investment data provides a convincing approach to evaluate the effects of IT investment on business performance (Hitt and Brynjolfsson, 1996; Stratopoulos and Dehning, 2000).

This study is designed to tackle the above three issues (the conceptual data, the time lag and the unequal performance of modeling techniques) in the following ways. First, a four-year operating dataset was collected from the government and along with audited company financial statements. This allowed us to examine the relationship between IT investment and firm performance using real data (as opposed to conceptual or opinion-based data) also with the consideration of the time lag effect. Based on the actual operating and financial data of companies, our results provide useful empirical evidence to help firms to overcome problems related to the IT productivity paradox, to increase the effectiveness of investment in IT, and to reduce operating costs in order to gain competitive advantage. Second, unlike conventional studies, we further evaluate the predictive power of models using both statistical and data mining techniques. More specifically multiple regression analysis and artificial neural networks (ANN) are used for their popularity in modeling financial performance. Insights are also uncovered through moderating analysis and canonical correlation. Through a performance comparison of these two algorithms on key indicators relating to IT investment, it is possible to gain more insight into the relationship of IT investment and firm performance.

The organization of this paper is as follows. Section 2 reviews previous research related to the value generation from IT investment, and the artificial neural network. Section 3 provides definitions for five independent variables and six dependent variables in our models. Section 4 discusses the preparation of data, experimental setup, and performance measures. Section 5 presents experimental results and discussions. Section 6 concludes this paper.

\section{Literature Review}

\section{IT Productivity Paradox and Value Generation from IT Investment}

In past decades, enterprises sought solutions to maintain competitive advantage within a global environment. Shafer and Byrd (2000) pointed out that many firms have considered IT as an effective means to find a niche in fluctuating global markets, considering the benefits it can bring to businesses including such things as cost reduction, improvements in quality, enhancement of flexibility, heightened customer satisfaction, and stricter operational enforcement. However, no obvious monetary evidence has been observed to actually demonstrate the benefits of investment in IT. This phenomenon is called the "IT productivity paradox".

Turban (2001) divided the "IT productivity paradox" into three categories. First, the impact of IT investment on productivity differs according to the industry. For example, the performance of a company in the manufacturing industry can be measured directly by considering the quantity or quality of its output. In contrast, the output of service industries, such as the customer satisfactory index, is usually more difficult to define or evaluate. In addition, firms need to spend time 
The Influence of IT Investment on Business Performance/ Hung. et al.

implementing IT, and during this phase productivity is not necessarily increased but may actually decline. This phenomenon is known as the time-lag effect. Second, the benefits provided by IT are counteracted by the cost of implementing it, including the over budget of software development, the maintenance of software and hardware, and the required input of extra labor. Third, the enhancement of productivity brought about by IT may be offset by other factors such as changes in the organizational structure, resistance from employees, and inappropriate layoff plans. Therefore, it is suggested that, in the evaluation of the inputs of IT investment, firms consider factors such as human resources, other IT projects, and system maintenance costs. Brynjolfsson (1993) suggested four possible reasons for the IT productivity paradox: (1) the inadequate measurement of total IT investment (i.e., input) and the total value generated from it (i.e., output); (2) the effect of the time lag between input and output; (3) the compensation of extra input by enhanced output; and (4) the improper management of IT resources. Note that all of the aforementioned issues are related to the management of IT rather than IT itself. Therefore, although the IT productivity paradox highlights the myths of IT implementation, firms should have no doubt about the potential benefits offered by IT.

Previous studies on the definition of business value from IT investment have relied mainly on increases in productivity or benefits and decreases in costs or stock (Brynjolfsson and Yang, 1997; Devaraj and Kohli, 2003; Hitt and Brynjolfsson, 1996; Joshi and Pant, 2008; Laudon and Laudon, 2006; O'Brien, 1995; Whisler and Leavitt, 1958). Zuboff (1998) believed that IT is capable of providing prompt information and improving business processes. In addition, other researchers have pointed out that IT can speed up product life cycles, increase customer satisfaction, and increase inventory turnover (Barua et al., 1995; Devaraj and Kohli, 2000; McAfee, 2002).

Melville et al. (2004) proposed the concept of the "IT Business Value Generation Process," addressing how IT investment interacts with other resources to generate business value for firms. The business value gained from investment in IT includes enhanced efficiency in business processes and improved organizational performance. The former includes customer service, flexibility, the sharing of information, and inventory control. The latter covers expanded productivity, efficiency, benefits, market value, and competitive advantage.

\section{Artificial Neural Networks Model}

The Artificial neural network (ANN) has been shown to have an extraordinary performance in classification and prediction applications. Its basic idea is to imitate the biological structure of the human brain to learn and identify patterns. The concept of ANNs was first introduced by McCulloch and Pitts (1990). Since its inability to solve some simple tasks, such as XOR, McClelland and Rumelhart (1989) proposed the back-propagation network algorithm (BPN), which can deal with more complex problems. BPN are non-linear statistical data modeling tools, and they can be used to deal with complex relationships between inputs and outputs. With the coming of BPN, plenty of ANNs-based researches have been addressed and the results show that ANNs-based methods can achieve good accuracy and retain robustness in various complex classification tasks. ANNs-based methods are then successfully applied to a wide range of real-life applications, such as finance forecasting, engineering, education, medicine, and so on (Awodele and Jegede, 2009; Bodyanskiy and Popov, 2006; Pao, 2008; Ringwood and Galvin, 2002; Stavrou et al., 2007; Tang and Fishwick, 1993; Zhang et al., 2001).

The topology of a BPN structure is shown in Figure 1. Basically, a neural network is composed of processing units, called neurons. There exist three kinds of layers in a BPN, including an input layer, one or more hidden layers, and an output layer. Neurons between two adjacent layers are fully-connected. Each neuron can receive inputs, process them, and 
The Influence of IT Investment on Business Performance/Hung. et al.

then pass on a single output to other linked neurons (input or hidden layer) or as the final result (output layer). Connection weights are the key elements in the learning procedure of BPN. Each weight represents the strength of the connection between two neurons. During the training/learning of a network, the BPN iteratively adjust connection weights for minimizing the difference between the computed output value from BPN and the desired output value. The adjustment of two parameters, including learning rate and momentum, is critical during the learning process. The learning rate, ranging from 0 to 1 , determines the degree of convergence. A higher learning rate may result in achieving the minimum error quickly, but may also lead to an MLP model periodically fluctuating around the solution without being able to converge. However, a lower learning rate may result in a local minimum or long time to converge. Thus, this study suggests using a higher learning rate at the beginning of model construction then adjusting the learning rate to a smaller value to achieve a minimal error. Because an inappropriate momentum may also cause a MLP model to fail converging, a similar recommendation is also valid for the momentum.

\section{Input layer Hidden layer Output layer}

Figure 1 - The network structure of BPN model.

\section{Research Methodology}

\section{Data}

The data in this study was collected from two main sources. First, the hardware, software, maintenance, and training costs of the sample companies were obtained from a survey by The Ministry of Economic Affairs, Executive Yuan in Taiwan. Second, the financial ratios such as Return on Assets (ROA), Operating Income to Sales Ratio (OI/S), Operating Income to Employees Ratio (OI/E), Cost of Goods Sold to Sales (COGS/S), Selling and 
The Influence of IT Investment on Business Performance/ Hung. et al.

General Administrative Expenses to Sales (SGA/S), and Total Operating Expenses to Sales (OPEXP/S), were obtained from public financial reports from the Taiwan Economic Journal (TEJ) database. The TEJ database has been recognized as the most authoritative financial database in Taiwan, providing high quality, in-depth, and up-to-date financial data as well as corporate information specific to Asia.

The sample for the present study includes 168 companies in the Taiwanese stock market. Considering the possible time lag effect following an IT investment, we collected the cost information of IT investment for the year 2000 as well as their public financial data for the years of 2000, 2001, 2002 and 2003. This time frame is carefully selected to avoid major political and economic confounding variables that became severe after 2003. For example, Taiwan's renunciation of the Guidelines for National Unification in 2004 and China's Anti-Secession Law passed in 2005 have both created major political angst leading to a very large scale protest against Taiwan's president in 2006. Moreover, the fourth direct election for the President of Taiwan was held in 2008.Compounded with a series of global financial crises from 2007 to 2012, Taiwan's Index of Investor Optimism became negative early in 2004. These events all had an impact on the financial market causing volatility that lasted for some time. The year 2000 represents the base year (or year one).Brynjolfsson (1993) and Brynjolfsson and Hitt (1998) show that a time lag could cause the IT investment efficacy to become apparent two to three years after the initial investment (Campbell, 2012). Therefore, data was also collected for the following three years after year one to capture the potential time lag effect of an IT investment.

To evaluate the predictive accuracy of the two models, we further divided the samples into a training set and a testing set. Based on Weiss and Kulikowski (1991) recommendation of 2-to-1 ratio between the training and the testing sets, we randomly selected 168 companies as the training set, leaving the remaining 84 companies in the testing set.

\section{Variables Relating to IT Investment}

Lacking a standard set of variables relating to IT investment is probably the number one reason for the divergence in the variable selection among the studies (Liang et al., 2010; Lim et al., 2011; Osei-Bryson and Ko, 2004; Zhu and Kraemer, 2002). Based on a careful examination of related literature (see Table 1), the following five independent variables emerge as the main sources of influence for the dependent variables.

The first independent variable is the ratio of IT investment to total investment (IT Investment Ratio). Previous studies divided IT investment into four categories: hardware costs, software costs, maintenance costs, and training costs (Sircar et al., 2000; Sriram and Stump, 2004; Weill, 1992). Hardware costs include the purchase of new hardware, depreciation costs, and/or the rental of IT equipment. Software costs include the purchase of software packages, costs associated with the development of tailor-made software, and the design costs of outsourcing software. Maintenance costs include those of operating, upgrading, and repairing software and hardware. 


\begin{tabular}{|c|c|c|}
\hline $\begin{array}{l}\text { Type of } \\
\text { variables }\end{array}$ & Variable name & Previous studies \\
\hline \multirow[t]{5}{*}{$\begin{array}{l}\text { Independent } \\
\text { variable }\end{array}$} & IT Investment Ratio & $\begin{array}{l}\text { Campbell (2012); Weill (1992); Barua (1995); } \\
\text { Kim et al. (2009) }\end{array}$ \\
\hline & Maintenance Cost Ratio & $\begin{array}{l}\text { Turban et al. (2001); Wahby and } \\
\text { AL-Suhaibani (2002) }\end{array}$ \\
\hline & Industry & $\begin{array}{l}\text { Osei-Bryson and Ko (2004); Rai et al. (1997); } \\
\text { Zhu and Kraemer (2002) }\end{array}$ \\
\hline & Firm Size & Rai et al. (1997); Zhu and Kraemer (2002) \\
\hline & Capital Density & $\begin{array}{l}\text { Barua (1995); Girma et al. (2000); Loveman } \\
\text { (1994); Hitt and Brynjolfsson (1996); Rai et al. } \\
\text { (1997); Osei-Bryson and Ko (2004) }\end{array}$ \\
\hline \multirow[t]{6}{*}{$\begin{array}{l}\text { Dependent } \\
\text { variable }\end{array}$} & ROA & $\begin{array}{l}\text { Bharadwaj (2000); Barua (1995); Weill } \\
\text { (1992); Rai et al. (1997); Hitt and Brynjolfsson } \\
\text { (1996); Kim et al. (2009) }\end{array}$ \\
\hline & $\mathrm{OI} / \mathrm{S}$ & $\begin{array}{l}\text { Bharadwaj (2000); Santhanam and Hartono } \\
(2003)\end{array}$ \\
\hline & $\mathrm{OI} / \mathrm{E}$ & $\begin{array}{l}\text { Bharadwaj (2000); Santhanam and Hartono } \\
(2003)\end{array}$ \\
\hline & COGS/S & $\begin{array}{l}\text { Campbell (2012); Bharadwaj (2000); } \\
\text { Santhanam and Hartono (2003); Zhu and } \\
\text { Kraemer (2002) }\end{array}$ \\
\hline & SGA/S & $\begin{array}{l}\text { Bharadwaj (2000); Santhanam and Hartono } \\
\text { (2003); Zhu and Kraemer (2002) }\end{array}$ \\
\hline & OPEXP/S & $\begin{array}{l}\text { Bharadwaj (2000); Santhanam and Hartono } \\
\text { (2003); Mitra and Chaya (1996) }\end{array}$ \\
\hline
\end{tabular}

Note: ROA: Return on Assets; OI/S: Operating Income to Sales Ratio; OI/E: Operating Income to Employees Ratio; COGS/S: Cost of Goods Sold to Sales; SGA/S: Selling and General Administrative Expenses to Sales; OPEXP/S: Total Operating Expenses to Sales.

Training costs include all those related to training users and IT staff in the use of IT. Dehning and Richardson (2002) divided IT investment studies into three categories: IT spending, IT strategy, and IT management, and provided a framework that captures how IT investment impacts on the business process and in turn leads to the performance enhancement of a firm. Although IT investment has been measured in several ways, this study considers the percentage of the IT investment budget to the total investment (termed IT investment intensity in Harris and Katz, 1989 and other related studies).

The second independent variable is the ratio of the maintenance costs to the IT investment (Maintenance Cost Ratio). Previous studies suggest maintenance costs as another important factor related to IT investment (Turban et al., 2001; Wahby and AL-Suhaibani, 2002). Therefore, except for the IT investment, this study also considers the ratio of maintenance costs to IT investment.

For the other three independent variables, some previous studies show that IT investment is influenced by the nature of the industry, the size of the firm, and the capital density (Girma et al. 2000; Osei-Bryson and Ko, 2004; Rai et al. ,1997; Zhu and Kraemer, 2002).Therefore, the third independent 
The Influence of IT Investment on Business Performance/ Hung. et al.

variable is the industry category (Industry) representing a binary variable. This variable indicates whether a firm is a high-tech company or not. More specifically, this study employs stock number as a key indicator to determine this. Listed companies with stock numbers between 2300 and 2499 were categorized as "high-tech" companies, while others were classified as "non high-tech companies."

The fourth independent variable is the size of the firm (Firm Size). According to the definition from the Small and Medium Enterprise Administration, Ministry of Economic Affairs, Taiwan, this term is defined as how much capital and how many employees a firm has.

The fifth independent variable is the density of capital (Capital Density). This study adopted net income to measure the size of companies to avoid the collinearity of the two independent variables, Firm Size and Capital Density. Capital density can then be defined as fixed cost / total cost. Because the nature of the high-tech industry is highly competitive and innovative, high-tech firms have to devote considerable capital to research and development to maintain their competitive edge.

In this study, we referred to Bharadwaj (2000) to derive six dependent variables for business performance which was classified into two categories: profit effectiveness performance and cost efficiency performance. According to Etzioni (1964), organizational effectiveness is the concept of how effective an organization is in achieving its intended goals. For profit-seeking firms, organizational effectiveness is commonly measured by their ability to use inputs for generating profits, so called profit effectiveness. In this study, the profit effectiveness perspective includes the following three variables: Return on Assets (ROA), Operating Income to Sales Ratio (OI/S), and Operating Income to Employees Ratio (Ol/E). The first dependent variable was ROA, a comprehensive variable commonly used to measure the effectiveness of using assets to generate profits (Grinyer and
Norburn, 1975). The second dependent variable, OI/S, focuses on the income generated from the main operating activities, excluding the gains or losses from non-operating activities such as investment in the stock market. McKeen and Smith (1993) argued that $\mathrm{OI} / \mathrm{S}$ is a suitable indicator for measuring the benefits of IT. The third dependent variable was $\mathrm{OI} / \mathrm{E}$, a measure of the profit generating ability of employees.

Cost efficiency is the measure of a firm's ability to use inputs (such as selling and general administration expenses) to produce sales. For example, the lower the ratio of selling and general administration expenses to sales is, the better is the firm's ability to generate its sales. The cost efficiency perspective includes the other three variables: Cost of Goods Sold to Sales (COGS/S), Selling and General Administrative Expenses to Sales (SGA/S), and Total Operating Expenses to Sales (OPEXP/S). The fourth dependent variable was COGS/S, a measure of production cost efficiency. The fifth dependent variable was SGA/S, an efficiency measure of selling and general administration activities. The sixth dependent variable was OPEXP/S. The total operating expense is the sum of general administration expenses and the cost of goods sold, which represents the total cost of all the operating activities of the firm (Mitra and Chaya, 1996). The aforementioned dependent variables can be found in the public financial reports of firms listed.

Descriptive statistics of the variables mentioned above for all fours years are reported in Table 2.

\section{Predictive Model}

In this study, two predictive techniques, linear regression and ANN, were used to empirically examine the relationships between IT investment and business performance. We used SPSS 11.0.1 for regression analysis. We also used Neuro Shell 2 developed by Ward Systems Group to build a BPN model. 
The Influence of IT Investment on Business Performance/Hung. et al.

\section{Regression Model}

Referring to the study of Hitt and Brynjolfsson
(1996), this study employed the productivity function of Cobb-Douglas to derive the basic function as follows:

\begin{tabular}{|l|c|c|}
\hline \multicolumn{1}{|c|}{ Table 2 - Statistical information for the collected companies. } \\
\hline IT Investment Ratio (2000) & Mean & Standard deviation \\
\hline Maintenance Cost Ratio (2000) & 0.5590 & 1.6869 \\
\hline Industry (2000) & 15.1352 & 15.0629 \\
\hline Firm Size (2000) & high tech / non-high tech: $74(44.05 \%) / 94(55.95 \%)$ \\
\hline Capital Density (2000) & $8,006,666$ & $12,447,930$ \\
\hline ROA (2000) & 30.3737 & 18.9366 \\
ROA (2001) & 7.2846 & 6.7691 \\
ROA (2002) & 5.1493 & 5.8925 \\
ROA (2003) & 5.2505 & 5.2790 \\
\hline OI/S (2000) & 5.8684 & 5.1155 \\
OI/S (2001) & 0.8209 & 0.1302 \\
OI/S (2002) & 0.8490 & 0.1494 \\
OI/S (2003) & 0.8393 & 0.1375 \\
\hline OI/E (2000) & 0.8358 & 0.1392 \\
OI/E (2001) & 0.0869 & 0.0573 \\
OI/E (2002) & 0.0984 & 0.0715 \\
OI/E (2003) & 0.0917 & 0.0732 \\
\hline COGS/S (2000) & 0.0920 & 0.1169 \\
COGS/S (2001) & 0.1049 & 0.0670 \\
COGS/S (2002) & 0.1200 & 0.0807 \\
COGS/S (2003) & 0.1125 & 0.0812 \\
\hline SGA/S (2000) & 0.1138 & 0.1209 \\
SGA/S (2001) & 8.3785 & 9.0204 \\
SGA/S (2002) & 6.1182 & 8.1233 \\
SGA/S (2003) & 6.8278 & 7.2628 \\
OPEXP/S (2000) & 7.2398 & 7.4692 \\
OPEXP/S (2001) & 754.4104 & 1056.9985 \\
OPEXP/S (2002) & 561.2001 & 924.9722 \\
OPEXP/S (2003) & 744.2212 & 1041.8040 \\
\hline
\end{tabular}

Note: ROA: Return on Assets; OI/S: Operating Income to Sales Ratio; OI/E: Operating Income to Employees Ratio; COGS/S: Cost of Goods Sold to Sales; SGA/S: Selling and General Administrative Expenses to Sales; OPEXP/S: Total Operating Expenses to Sales.

$\hat{Y}_{j}=X_{1}^{\beta_{j, 1}} X_{2}^{\beta_{j, 2}} X_{3}^{\beta_{j, 3}} X_{4}^{\beta_{j, 4}} X_{5}^{\beta_{j, 5}}+\varepsilon$

where $\beta_{j, i}$ denotes the regression coefficient of $Y_{j}$ on $X_{i}(i=1$ to 5$)$; and $Y_{j}(j=1$ to 6$)$ denotes the dependent variable defined previously (i.e. ROA, OI/S, OI/E, COGS/S, SGA/S, and OPEXP/S). After taking a natural log, we derived the following equation: $\ln \hat{Y}_{j}=\beta_{j, 1} \ln X_{1}+\ldots+\beta_{j, 5} \ln X_{5}+\varepsilon$

For each year, therefore, we can infer its regression equation by applying the equation as follows.

$\ln \hat{Y}_{j(t)}=\beta_{j, 1} \ln X_{1}+\ldots+\beta_{j, 5} \ln X_{5}+\varepsilon$

where $t=1$ represents business performance for the year 2000 leading to lag=0; $t=2$ 
The Influence of IT Investment on Business Performance/ Hung. et al.

represented in the year 2001 leading to lag $=1$; $t=3$ represented in the year 2002 leading to lag $=2 ; t=4$ represented in the year 2003 leading to lag $=3$.

\section{BPN Model}

In addition to the regression model, this study applied the BPN model to evaluate effectiveness and compare the differences between the two models. All variables are the same as those used in the regression models.

Because the number of neurons in the hidden layer may influence the performance of a BPN model, this study adopted the approach of Davies (1994) which suggests that trial-and-error is a feasible way to determine the number of neurons in a hidden layer. By utilizing this trial-and-error method, our study set the number of neurons in the hidden layer at 16.

In the process of constructing BPN models, the learning rate and the momentum factor influence the speed of model building. An inappropriate degree of momentum may lead to a BPN model failing to converge. A higher learning rate may result in rapidly achieving the minimum number of errors, but it may also lead to the BPN model periodically fluctuating around the solution with an inability to converge. However, a lower learning rate may result in a local minimum or delays in convergence. The use of a higher learning rate is suggested at the beginning of the model construction with the learning rate then adjusted to a lower value to achieve minimum error. The same recommendation is also valid for the momentum. Therefore, this study set the initial values of the momentum and learning rate at 0.5 and 1 , respectively, according to the study of Nam and Schaefer (1995). We fine-tuned both the momentum and the rate of learning according to the progress of convergence.

\section{Performance Measure}

This study employed a training set to build up both the regression models and the BPN models and a testing set to examine the performance of the models. After building the models, we used the coefficient of determination $\left(R^{2}\right)$, root mean square error (RMSE), and mean absolute error (MAE), to examine the effects of a time lag and performance in both the regression and BPN models. We then applied the t-test to examine the differences between real values and estimated values. The equations used to calculate the values of RMSE and MAE are listed below:

$$
\begin{aligned}
& \text { RMSE }=\sqrt{\frac{\sum\left(y_{j(t)}-\hat{y}_{j(t)}\right)^{2}}{N}} \\
& M A E=\frac{\sum\left|y_{j(t)}-\hat{y}_{j(t)}\right|}{N}
\end{aligned}
$$

where $y_{j(t)}$ represents the real value of $y_{t}, \hat{y}_{j(t)}$ represents the estimated value of $y_{t}$; and $N$ represents the number of samples.

\section{Results and Discussions}

\section{Canonical Correlation Analysis}

Before examining individual linear relationships between the independent variables against each dependent variable, it is useful to first look at the linear relationship of the two sets of variables through canonical correlation analysis. The first set of variables (i.e., the dependent variables) includes two categories of performance indicators, such as ROA, COGS/S, SGA/S, OI/E, OPEXP/S, and $\mathrm{OI} / \mathrm{S}$. The second set (i.e., the independent variables) includes IT Investment Ratio, Maintenance Cost Ratio, Industry, Firm Size and Capital Density. The general procedure of canonical correlation analysis applied to this study includes the multivariate significance test of the full model (using Pillai's, Hotelling's, Wilk's and Roy's statistics), selection of canonical functions, and the analysis of significance. Tables 3 and 4 report the first two canonical functions that bear statistical significance based on the dimension reduction analysis. Standardized coefficients are reported in the first column for each year, while canonical loadings are in the second 
The Influence of IT Investment on Business Performance/Hung. et al.

column. Loadings higher than 0.30 are in bold face to highlight their relative weights to their respective canonical variates.

The full model was statistically significant for all four years. The canonical correlations are quite consistent among the years, ranging from .651 to .710 for the first canonical function and .564 to .603 for the second function. It is expected that the correlations decrease from the first function to the second due to the nature of the canonical correlation algorithm that aims to maximize the correlations in the first function, leaving the rest of the functions to interpret the remaining part of the unexplained variance. The independent variable set in the first canonical function interprets mostly OI/E, while the set is related more to OI/S, OI/E and COGS/S in the second function. In other words, the largest variance explained by the set of independent variables is a profit effectiveness indicator (i.e., $\mathrm{Ol} / \mathrm{E})$ in the first canonical function, which continues to be the case into the second canonical function that explains two profit effectiveness indicators (OI/S and $\mathrm{OI} / \mathrm{E}$ ) and one cost efficiency indicator (COGS/S). As such, the effect of IT investment is more for profit effectiveness than for cost efficiency (or cost reduction), which provides evidence beyond some anecdotal reports that predominantly associate IT investment with only cost reduction. It would appear that ROA, SGA/S and OPEXP/S might not have been predicted very accurately by the set of independent variables and are therefore subject to elimination, if Sircar et al.'s (2000) procedure for variable elimination is performed. Unlike their study, the dimension reduction analysis performed on our data set also suggested that a third canonical function was indeed possible and statistically significant for most years except 2003. This third function shows that these three dependent variables are indeed predicted by the independent variables. Since the third canonical function tends to have an even smaller correlation coefficient, the variance of dependent variables interpreted by the independent variables has a smaller practical significance. Using Sircar et al.'s (2000) approach, we retained all dependent variables, noting that there might be a varying degree of interpretability of them by the independent variables. This leads us to the next section where the independent variables on each dependent variable are examined individually.

\begin{tabular}{|c|c|c|c|c|c|c|c|c|}
\hline \multirow[b]{2}{*}{ Variable } & \multicolumn{2}{|c|}{ Year 2000} & \multicolumn{2}{|c|}{ Year 2001} & \multicolumn{2}{|c|}{ Year 2002} & \multicolumn{2}{|c|}{ Year 2003} \\
\hline & $\begin{array}{l}\text { Std. } \\
\text { Coef. }\end{array}$ & $\begin{array}{l}\text { Struct. } \\
\text { Coef. }\end{array}$ & $\begin{array}{l}\text { Std. } \\
\text { Coef. }\end{array}$ & $\begin{array}{l}\text { Struct. } \\
\text { Coef. }\end{array}$ & $\begin{array}{l}\text { Std. } \\
\text { Coef. }\end{array}$ & $\begin{array}{l}\text { Struct. } \\
\text { Coef. }\end{array}$ & $\begin{array}{l}\text { Std. } \\
\text { Coef. }\end{array}$ & $\begin{array}{c}\text { Struct. } \\
\text { Coef. }\end{array}$ \\
\hline ROA & -0.331 & 0.684 & -0.011 & 0.242 & -0.155 & 0.152 & -0.232 & 0.051 \\
\hline SGA/S & -0.615 & 0.532 & 0.065 & 0.134 & 0.085 & 0.171 & 0.201 & 0.272 \\
\hline OPEXP/S & -0.534 & 0.300 & -0.001 & 0.183 & -0.008 & 0.151 & -0.020 & 0.089 \\
\hline $\mathrm{OI} / \mathrm{S}$ & -0.143 & -0.347 & 0.214 & -0.047 & 0.067 & -0.084 & 0.017 & -0.110 \\
\hline Ol/E & -1.850 & -0.196 & -2.508 & -0.375 & -2.481 & -0.426 & -2.302 & -0.412 \\
\hline COGS/S & 1.810 & 0.162 & 2.408 & 0.026 & 2.270 & -0.018 & 2.098 & 0.006 \\
\hline $\begin{array}{l}\text { IT Investment } \\
\text { Ratio }\end{array}$ & 0.209 & 0.527 & 0.071 & 0.308 & 0.037 & 0.286 & 0.071 & 0.328 \\
\hline $\begin{array}{l}\text { Maintenance } \\
\text { Cost Ratio }\end{array}$ & -0.094 & -0.371 & -0.094 & -0.331 & -0.081 & -0.333 & -0.092 & -0.345 \\
\hline
\end{tabular}


The Influence of IT Investment on Business Performance/ Hung. et al.

\begin{tabular}{|c|c|c|c|c|c|c|c|c|}
\hline Industry & 0.915 & 0.927 & 0.942 & 0.929 & 0.939 & 0.925 & 0.915 & 0.935 \\
\hline Firm Size & 0.019 & -0.032 & 0.306 & 0.284 & 0.332 & 0.376 & 0.309 & 0.376 \\
\hline $\begin{array}{l}\text { Capital } \\
\text { Density }\end{array}$ & 0.283 & 0.029 & 0.191 & -0.082 & 0.149 & -0.149 & 0.133 & -0.196 \\
\hline & \multicolumn{2}{|c|}{$\begin{array}{l}\text { CC: } 0.710, \\
C^{2}: 0.504\end{array}$} & \multicolumn{2}{|c|}{$\begin{array}{l}\text { CC: } 0.652, \\
C C^{2}: 0.425\end{array}$} & \multicolumn{2}{|c|}{$\begin{array}{l}\text { CC: } 0.651, \\
C C^{2}: 0.424\end{array}$} & \multicolumn{2}{|c|}{$\begin{array}{l}\text { CC: } 0.675, \\
C C^{2}: 0.456\end{array}$} \\
\hline
\end{tabular}

Note: ROA: Return on Assets; OI/S: Operating Income to Sales Ratio; OI/E: Operating Income to Employees Ratio; COGS/S: Cost of Goods Sold to Sales; SGA/S: Selling and General Administrative Expenses to Sales; OPEXP/S: Total Operating Expenses to Sales; CC: canonical correlation; $\mathrm{CC}^{2}$ : canonical correlation squared; Struct. Coef: structure coefficient; Std. coef: standardized coefficient.

\section{Table 4 - Second Canonical Function - Years 2000 to 2003}

\begin{tabular}{|l|c|c|c|c|c|c|c|c|}
\hline & \multicolumn{2}{|c|}{ Year 2000} & \multicolumn{2}{c|}{ Year 2001} & \multicolumn{2}{c|}{ Year 2002} & \multicolumn{2}{c|}{ Year 2003 } \\
\hline Variable & $\begin{array}{c}\text { Std. } \\
\text { Coef. }\end{array}$ & $\begin{array}{c}\text { Struct. } \\
\text { Coef. }\end{array}$ & $\begin{array}{c}\text { Std. } \\
\text { Coef. }\end{array}$ & $\begin{array}{c}\text { Struct. } \\
\text { Coef. }\end{array}$ & $\begin{array}{c}\text { Std. } \\
\text { Coef. }\end{array}$ & $\begin{array}{c}\text { Struct. } \\
\text { Coef. }\end{array}$ & $\begin{array}{c}\text { Std. } \\
\text { Coef. }\end{array}$ & $\begin{array}{c}\text { Struct. } \\
\text { Coef. }\end{array}$ \\
\hline ROA & -0.145 & -0.123 & -0.250 & 0.030 & -0.131 & 0.029 & -0.498 & $\mathbf{- 0 . 3 1 4}$ \\
\hline SGA/S & 0.877 & 0.179 & 1.047 & 0.199 & 0.981 & 0.243 & 0.385 & 0.013 \\
\hline OPEXP/S & -0.966 & $\mathbf{- 0 . 3 6 9}$ & -0.891 & -0.210 & -0.946 & $\mathbf{- 0 . 3 4 8}$ & -0.070 & -0.158 \\
\hline OI/S & -0.379 & $\mathbf{- 0 . 4 2 5}$ & -0.145 & $-\mathbf{- 0 . 4 5 5}$ & -0.154 & $\mathbf{- 0 . 4 1 5}$ & -0.095 & $\mathbf{- 0 . 4 7 8}$ \\
\hline OI/E & 0.749 & $\mathbf{0 . 7 2 8}$ & -0.147 & $\mathbf{0 . 7 1 8}$ & 0.021 & $\mathbf{0 . 6 4 0}$ & 0.212 & $\mathbf{0 . 8 5 1}$ \\
\hline COGS/S & -0.378 & $\mathbf{0 . 6 3 1}$ & 0.833 & $\mathbf{0 . 7 8 3}$ & 0.509 & $\mathbf{0 . 7 0 4}$ & 0.669 & $\mathbf{0 . 9 0 0}$ \\
\hline & & & & & & & & \\
\hline $\begin{array}{l}\text { IT Investment } \\
\text { Ratio }\end{array}$ & 0.356 & $\mathbf{0 . 5 0 1}$ & 0.388 & $\mathbf{0 . 5 7 6}$ & 0.386 & $\mathbf{0 . 5 5 1}$ & 0.482 & $\mathbf{0 . 6 7 3}$ \\
\hline $\begin{array}{l}\text { Maintenance } \\
\text { Cost Ratio }\end{array}$ & -0.047 & -0.133 & 0.023 & -0.102 & -0.094 & -0.159 & -0.030 & -0.157 \\
\hline Industry & -0.259 & -0.242 & 0.141 & 0.121 & 0.201 & 0.095 & 0.176 & 0.185 \\
\hline Firm Size & -0.725 & $\mathbf{0 . 8 1 0}$ & -0.710 & $\mathbf{- 0 . 7 8 8}$ & -0.599 & $\mathbf{- 0 . 6 1 6}$ & -0.746 & $\mathbf{- 0 . 8 0 6}$ \\
\hline $\begin{array}{l}\text { Capital } \\
\text { Density }\end{array}$ & 0.392 & $\mathbf{0 . 4 2 1}$ & 0.502 & $\mathbf{0 . 4 0 3}$ & 0.692 & $\mathbf{0 . 5 5 6}$ & 0.269 & 0.138 \\
\hline & & & & & & & & \\
\hline & CC: & 0.603, & CC: & 0.567, & CC: 0.586, & CC: 0.564, \\
\hline
\end{tabular}


The Influence of IT Investment on Business Performance/Hung. et al.

\section{Collinearity Analysis}

By checking the distribution of error terms for all dependent variables, we did not find any significant co-linearity problems for ROA, OI/S, SGA/S, OPEXP/S, and COGS/S. The tolerance and variance inflation factor (VIF) information for all independent variables is shown in Table 5 . The results show that all VIF values are close to 1 , implying no serious collinearity problem. Self-correlation did not exist among any of the variables and the error terms possessed independence. In addition, the histograms of dependent variables (not shown here) show that the error terms of ROA, OI/S, SGA/S and OPEXP/S met the requirements of a normal distribution, but OI/E and COGS/S did not.

\section{Results from Regression Models}

The first regression model includes ROA as the dependent variable, and IT Investment Ratio, Maintenance Cost Ratio, Industry, Firm Size and Capital Density as the independent variables. We then derived the regression model for the year 2000 and tabulated this model in Table 6. From Table 6, we find that Industry is significant at a level of $p<0.01$. In the same manner, the regression models for the years 2001, 2002, and 2003 were derived and tabulated in Table 6. For the year 2001, Maintenance Cost Ratio was significant at a level of $p<0.05$; IT Investment Ratio and Capital Density were significant at a level of $p<0.1$. For the year 2002, Maintenance Cost Ratio was significant at a level of $p<0.05$; Firm Size was significant at a level of $p<0.1$. For the year 2003, only Firm Size was significant at a level of $p<0.05$.

\begin{tabular}{|l|c|c|}
\hline \multicolumn{1}{|c|}{ Table 5 - Collinearity statistics. } \\
\hline \multicolumn{1}{|c|}{ Variable } & Tolerance & VIF \\
\hline IT Investment Ratio & 0.889 & 1.125 \\
\hline Maintenance Cost Ratio & 0.762 & 1.312 \\
\hline Industry & 0.782 & 1.279 \\
\hline Firm Size & 0.896 & 1.116 \\
\hline Capital Density & 0.904 & 1.107 \\
\hline
\end{tabular}

Table 6 - The first regression model. (Return on Assets, ROA)

\begin{tabular}{|l|c|c|c|c|c|}
\hline \multicolumn{7}{|c|}{ Year= 2000} \\
\hline & Coefficient & $\begin{array}{c}\text { Standard } \\
\text { Deviation }\end{array}$ & t value & Sig. & $\begin{array}{c}\text { Mark for } \\
\text { Significance }\end{array}$ \\
\hline Constant & 0.3391 & 1.6975 & 0.1998 & 0.8419 & \\
\hline $\begin{array}{l}\text { IT Investment } \\
\text { Ratio }\end{array}$ & 0.1231 & 0.0774 & 1.5897 & 0.1139 & \\
\hline $\begin{array}{l}\text { Maintenance } \\
\text { Cost Ratio }\end{array}$ & -0.0621 & 0.0859 & -0.7224 & 0.4711 & \\
\hline Industry & 1.2718 & 0.2230 & 5.7027 & 0.0000 & $* *$ \\
\hline Firm Size & 0.0569 & 0.1119 & 0.5090 & 0.6115 & \\
\hline Capital Density & -0.0328 & 0.1183 & -0.2772 & 0.7820 & \\
\hline \multicolumn{7}{|c|}{ Year= 2001 } \\
\hline Constant & 1.3737 & 2.0926 & 0.6565 & 0.5125 & \\
\hline $\begin{array}{l}\text { IT Investment } \\
\text { Ratio }\end{array}$ & 0.1630 & 0.0931 & 1.7499 & 0.0820 & $*$ \\
\hline $\begin{array}{l}\text { Maintenance } \\
\text { Cost Ratio }\end{array}$ & -0.2262 & 0.1050 & -2.1552 & 0.0326 & $*$ \\
\hline Industry & 0.1151 & 0.2703 & 0.4258 & 0.6708 & \\
\hline Firm Size & 0.0659 & 0.1357 & 0.4860 & 0.6276 & \\
\hline
\end{tabular}


The Influence of IT Investment on Business Performance/ Hung. et al.

\begin{tabular}{|l|c|c|c|c|l|}
\hline Capital Density & -0.2810 & 0.1478 & -1.9018 & 0.0590 & $*$ \\
\hline \multicolumn{5}{|c|}{ Year= 2002 } \\
\hline Constant & -1.7004 & 1.8818 & -0.9036 & 0.3675 & \\
\hline $\begin{array}{l}\text { IT Investment } \\
\text { Ratio }\end{array}$ & 0.0979 & 0.0907 & 1.0791 & 0.2822 & \\
\hline $\begin{array}{l}\text { Maintenance } \\
\text { Cost Ratio }\end{array}$ & -0.2602 & 0.1036 & -2.5120 & 0.0130 & ** \\
\hline Industry & -0.1336 & 0.2695 & -0.4955 & 0.6209 & \\
\hline Firm Size & 0.2066 & 0.1210 & 1.7072 & 0.0897 & * \\
\hline Capital Density & 0.0626 & 0.1360 & 0.4605 & 0.6458 & \\
\hline \multicolumn{7}{|c|}{ Year= 2003 } & & \\
\hline Constant & -1.8510 & 1.5757 & -1.1747 & 0.2418 & \\
\hline $\begin{array}{l}\text { IT Investment } \\
\text { Ratio }\end{array}$ & -0.0063 & 0.0813 & -0.0776 & 0.9383 & \\
\hline $\begin{array}{l}\text { Maintenance } \\
\text { Cost Ratio }\end{array}$ & -0.0933 & 0.0923 & -1.0101 & 0.3140 & \\
\hline Industry & -0.2508 & 0.2467 & -1.0166 & 0.3109 & \\
\hline Firm Size & 0.2429 & 0.1010 & 2.4051 & 0.0173 & ** \\
\hline Capital Density & -0.1493 & 0.1267 & -1.1783 & 0.2404 & \\
\hline
\end{tabular}

The second regression model includes OI/S as the dependent variable with the same set of independent variables. The regression models representing the years 2000, 2001, 2002, and 2003 are tabulated in Table 7. The results indicate that: Maintenance Cost Ratio and Industry were significant at levels of $p<0.1$ and $p<0.01$, respectively, for the year 2000; Maintenance Cost Ratio and Capital Density were significant at levels of $p<0.01$ and $p<0.1$, respectively, for the year 2001;IT Investment Ratio and Maintenance Cost Ratio were significant at levels of $p<0.1$ and $p<0.01$, respectively, for the year 2002; IT Investment Ratio and Maintenance Cost Ratio were significant at levels of $p<0.05$ and $p<0.01$, respectively, for the year 2003.

The third regression model considered OI/E as the dependent variable with the same set of independent variables. The regression models are tabulated in Table 8 . The results show that: Capital Density was significant at a level of $p<0.01$ for the year 2000; Maintenance Cost Ratio was significant at a level of $p<0.05$ for the year 2001; IT Investment Ratio, Maintenance Cost Ratio and Firm Size were significant at levels of $p<0.05, p<0.01$ and $p<0.01$, respectively, for the year 2002; IT Investment Ratio and Firm Size were significant at levels of $p<0.1$ and $p<0.01$, respectively, for the year 2003 . 


\section{Table 7 - The second regression model. (Operating Income to Sales Ratio, OI/S)}

\begin{tabular}{|c|c|c|c|c|c|}
\hline \multicolumn{6}{|c|}{ Year= 2000} \\
\hline & Coefficient & $\begin{array}{l}\text { Standard } \\
\text { Deviation }\end{array}$ & t value & Sig. & $\begin{array}{c}\text { Mark for } \\
\text { Significance }\end{array}$ \\
\hline Constant & 2.6036 & 2.0547 & 1.2672 & 0.2069 & \\
\hline $\begin{array}{l}\text { IT Investment } \\
\text { Ratio }\end{array}$ & 0.1491 & 0.0937 & 1.5906 & 0.1137 & \\
\hline $\begin{array}{l}\text { Maintenance } \\
\text { Cost Ratio }\end{array}$ & -0.1926 & 0.1040 & -1.8514 & 0.0659 & * \\
\hline Industry & 0.9040 & 0.2699 & 3.3491 & 0.0010 & $\star * *$ \\
\hline Firm Size & -0.1060 & 0.1354 & -0.7831 & 0.4347 & \\
\hline Capital Density & 0.1882 & 0.1432 & 1.3139 & 0.1907 & \\
\hline \multicolumn{6}{|c|}{ Year $=2001$} \\
\hline Constant & 5.6657 & 2.4254 & 2.3360 & 0.0207 & ** \\
\hline $\begin{array}{l}\text { IT Investment } \\
\text { Ratio }\end{array}$ & 0.1511 & 0.1080 & 1.3997 & 0.1635 & \\
\hline $\begin{array}{l}\text { Maintenance } \\
\text { Cost Ratio }\end{array}$ & -0.3242 & 0.1216 & -2.6654 & 0.0085 & $* * *$ \\
\hline Industry & -0.0050 & 0.3133 & -0.0160 & 0.9873 & \\
\hline Firm Size & -0.2010 & 0.1572 & -1.2784 & 0.2030 & \\
\hline Capital Density & -0.2952 & 0.1713 & -1.7235 & 0.0867 & * \\
\hline \multicolumn{6}{|c|}{ Year $=2002$} \\
\hline Constant & -0.1540 & 1.9913 & -0.0774 & 0.9384 & \\
\hline $\begin{array}{l}\text { IT Investment } \\
\text { Ratio }\end{array}$ & 0.1737 & 0.0960 & 1.8098 & 0.0722 & * \\
\hline $\begin{array}{l}\text { Maintenance } \\
\text { Cost Ratio }\end{array}$ & -0.3887 & 0.1096 & -3.5453 & 0.0005 & $* * *$ \\
\hline Industry & -0.1226 & 0.2852 & -0.4299 & 0.6678 & \\
\hline Firm Size & 0.1199 & 0.1280 & 0.9361 & 0.3506 & \\
\hline Capital Density & 0.2108 & 0.1439 & 1.4646 & 0.1450 & \\
\hline \multicolumn{6}{|c|}{ Year= 2003} \\
\hline Constant & -2.0219 & 1.7386 & -1.1630 & 0.2465 & \\
\hline $\begin{array}{l}\text { IT Investment } \\
\text { Ratio }\end{array}$ & 0.1898 & 0.0897 & 2.1167 & 0.0358 & $* *$ \\
\hline $\begin{array}{l}\text { Maintenance } \\
\text { Cost Ratio }\end{array}$ & -0.1897 & 0.1019 & -1.8619 & 0.0644 & * \\
\hline Industry & 0.0411 & 0.2722 & 0.1508 & 0.8803 & \\
\hline Firm Size & 0.2505 & 0.1114 & 2.2485 & 0.0259 & $* *$ \\
\hline Capital Density & 0.0601 & 0.1398 & 0.4301 & 0.6677 & \\
\hline
\end{tabular}

Notes: ${ }^{* *} p<0.01 ;{ }^{* *} p<0.05 ;{ }^{*} p<0.1$ 


\begin{tabular}{|c|c|c|c|c|c|}
\hline \multicolumn{6}{|c|}{ Year $=2000$} \\
\hline & Coefficient & $\begin{array}{l}\text { Standard } \\
\text { Deviation }\end{array}$ & $\mathrm{t}$ value & Sig. & $\begin{array}{c}\text { Mark for } \\
\text { Significance }\end{array}$ \\
\hline Constant & -0.4401 & 6.3313 & -0.0695 & 0.9947 & \\
\hline IT Investment Ratio & 0.2136 & 0.2888 & 0.7393 & 0.4608 & \\
\hline $\begin{array}{l}\text { Maintenance Cost } \\
\text { Ratio }\end{array}$ & -0.2217 & 0.3205 & -0.6916 & 0.4901 & \\
\hline Industry & 2.3630 & 0.8318 & 2.8409 & 0.0051 & $* * *$ \\
\hline Firm Size & 0.2261 & 0.4173 & 0.5418 & 0.5587 & \\
\hline Capital Density & 0.2691 & 0.4413 & 0.6097 & 0.5429 & \\
\hline \multicolumn{6}{|c|}{ Year= 2001} \\
\hline Constant & 4.6279 & 7.4743 & 0.6192 & 0.5367 & \\
\hline IT Investment Ratio & 0.4401 & 0.3327 & 1.3229 & 0.1877 & \\
\hline $\begin{array}{l}\text { Maintenance Cost } \\
\text { Ratio }\end{array}$ & -0.8366 & 0.3749 & -2.2318 & 0.0270 & $* *$ \\
\hline Industry & -0.2397 & 0.9655 & -0.2483 & 0.8042 & \\
\hline Firm Size & 0.2048 & 0.4846 & 0.4227 & 0.6731 & \\
\hline Capital Density & -0.7942 & 0.5278 & -1.5047 & 0.1344 & \\
\hline \multicolumn{6}{|c|}{ Year= 2002} \\
\hline Constant & -10.4560 & 5.5358 & -1.8888 & 0.0607 & \\
\hline IT Investment Ratio & 0.5541 & 0.2668 & 2.0769 & 0.0394 & ** \\
\hline $\begin{array}{l}\text { Maintenance Cost } \\
\text { Ratio }\end{array}$ & -0.8503 & 0.3048 & -2.7900 & 0.0059 & $* * *$ \\
\hline Industry & -0.3643 & 0.7929 & -0.4594 & 0.6465 & \\
\hline Firm Size & 1.0375 & 0.3559 & 2.9147 & 0.0041 & *** \\
\hline Capital Density & 0.5351 & 0.4001 & 1.3376 & 0.1829 & \\
\hline \multicolumn{6}{|c|}{ Year $=2003$} \\
\hline Constant & -11.3962 & 4.6898 & -2.4300 & 0.0162 & ** \\
\hline IT Investment Ratio & 0.4742 & 0.2419 & 1.9606 & 0.0516 & * \\
\hline $\begin{array}{l}\text { Maintenance Cost } \\
\text { Ratio }\end{array}$ & -0.2239 & 0.2748 & -0.8148 & 0.4164 & \\
\hline Industry & -0.9032 & 0.7344 & -1.2300 & 0.2205 & \\
\hline Firm Size & 1.2275 & 0.3005 & 4.0843 & 0.0001 & $* * *$ \\
\hline Capital Density & -0.4142 & 0.3771 & -1.0983 & 0.2737 & \\
\hline
\end{tabular}

Notes: ${ }^{* * *} p<0.01 ;{ }^{* *} p<0.05 ;{ }^{*} p<0.1$

The fourth regression model considered COGS/S as dependent variables with the same set of independent variables. The regression models representing the years of 2000, 2001, 2002, and 2003 are tabulated in Table 9. The results reveal that: both IT Investment Ratio and Firm Size were significant at a level of $p<0.01$ for the year
2000; IT Investment Ratio, Firm Size and Capital Density were significant at the levels of $p<0.05, p<0.01$ and $p<0.1$, respectively, for the year 2001; IT Investment Ratio and Firm Size were significant at levels of $p<0.01$ and $p<0.1$, respectively, for the year 2002; IT Investment Ratio was significant at a level of $p<0.01$ for the year 2003 . 


\section{Table 9 - The fourth regression model. (Cost of Goods Sold to Sales, COGS/S)}

\begin{tabular}{|c|c|c|c|c|c|}
\hline \multicolumn{6}{|c|}{ Year $=2000$} \\
\hline & Coefficient & $\begin{array}{l}\text { Standard } \\
\text { Deviation }\end{array}$ & t value & Sig. & $\begin{array}{c}\text { Mark for } \\
\text { Significance }\end{array}$ \\
\hline Constant & -1.4350 & 0.3169 & -4.5286 & 0.0000 & $* \star * *$ \\
\hline $\begin{array}{l}\text { IT Investment } \\
\text { Ratio }\end{array}$ & -0.0436 & 0.0145 & -3.0185 & 0.0030 & *** \\
\hline $\begin{array}{l}\text { Maintenance } \\
\text { Cost Ratio }\end{array}$ & 0.0144 & 0.0160 & 0.8997 & 0.3696 & \\
\hline Industry & -0.0512 & 0.0416 & -1.2296 & 0.2206 & \\
\hline Firm Size & 0.0671 & 0.0209 & 3.2124 & 0.0016 & *** \\
\hline Capital Density & 0.0299 & 0.0221 & 1.3541 & 0.1776 & \\
\hline \multicolumn{6}{|c|}{ Year=2001 } \\
\hline Constant & -1.5775 & 0.3522 & -4.4785 & 0.0000 & $* * *$ \\
\hline $\begin{array}{l}\text { IT Investment } \\
\text { Ratio }\end{array}$ & -0.0408 & 0.0157 & -2.5972 & 0.0103 & ** \\
\hline $\begin{array}{l}\text { Maintenance } \\
\text { Cost Ratio }\end{array}$ & 0.0227 & 0.0177 & 1.2827 & 0.2014 & \\
\hline Industry & 0.0051 & 0.0455 & 0.1114 & 0.9114 & \\
\hline Firm Size & 0.0726 & 0.0228 & 3.1769 & 0.0018 & *** \\
\hline Capital Density & 0.0480 & 0.0249 & 1.9255 & 0.0559 & * \\
\hline \multicolumn{6}{|c|}{ Year=2002 } \\
\hline Constant & -0.9474 & 0.3289 & -2.8807 & 0.0045 & ** \\
\hline $\begin{array}{l}\text { IT Investment } \\
\text { Ratio }\end{array}$ & -0.0508 & 0.0159 & -3.2063 & 0.0016 & $* \star * *$ \\
\hline $\begin{array}{l}\text { Maintenance } \\
\text { Cost Ratio }\end{array}$ & 0.0282 & 0.0181 & 1.5577 & 0.1213 & \\
\hline Industry & 0.0067 & 0.0471 & 0.1421 & 0.8872 & \\
\hline Firm Size & 0.0379 & 0.0211 & 1.7907 & 0.0752 & * \\
\hline Capital Density & 0.0018 & 0.0238 & 0.0778 & 0.9381 & \\
\hline \multicolumn{6}{|c|}{ Year $=2003$} \\
\hline Constant & -0.8171 & 0.3203 & -2.5509 & 0.0117 & ** \\
\hline $\begin{array}{l}\text { IT Investment } \\
\text { Ratio }\end{array}$ & -0.0527 & 0.0165 & -3.1913 & 0.0017 & *** \\
\hline $\begin{array}{l}\text { Maintenance } \\
\text { Cost Ratio }\end{array}$ & 0.0215 & 0.0188 & 1.1479 & 0.2527 & \\
\hline Industry & 0.0069 & 0.0502 & 0.1369 & 0.8913 & \\
\hline Firm Size & 0.0276 & 0.0205 & 1.3461 & 0.1801 & \\
\hline Capital Density & 0.0119 & 0.0258 & 0.4615 & 0.6450 & \\
\hline
\end{tabular}

Notes: ${ }^{* * *} p<0.01 ;{ }^{* *} p<0.05 ;{ }^{*} p<0.1$

The fifth regression model considered SGA/S as the dependent variable with the same set of independent variables. The regression models representing the years 2000, 2001, 2002, and 2003 are tabulated in Table 10. The results show that: IT Investment Ratio, Industry, and Firm Size were significant at levels of $p<0.1, \quad p<0.01$ and $p<0.01$, respectively, for the year 2000; IT Investment Ratio, Industry and Firm Size were significant 
The Influence of IT Investment on Business Performance/ Hung. et al.

at levels of $p<0.1, \quad p<0.1, \quad$ and $p<0.01$, respectively,for the year 2001; IT Investment Ratio and Firm Size were significant at levels of $p<0.1$ and $p<0.01$, respectively, for the year 2002; IT Investment Ratio, Industry, and Firm Size were significant at levels of $p<0.05, p<0.1$, and $p<0.01$, respectively, for the year 2003 .

\begin{tabular}{|c|c|c|c|c|c|}
\hline \multicolumn{6}{|c|}{ Table 10 - The fifth regression $n$} \\
\hline \multicolumn{6}{|c|}{ Year= 2000} \\
\hline & Coefficient & $\begin{array}{l}\text { Standard } \\
\text { Deviation }\end{array}$ & $\mathrm{t}$ value & Sig. & $\begin{array}{c}\text { Mark for } \\
\text { Significance }\end{array}$ \\
\hline Constant & 1.4377 & 0.7256 & 1.9813 & 0.0493 & ** \\
\hline $\begin{array}{l}\text { IT Investment } \\
\text { Ratio }\end{array}$ & 0.0341 & 0.0367 & 0.9276 & 0.3550 & \\
\hline $\begin{array}{l}\text { Maintenance } \\
\text { Cost Ratio }\end{array}$ & 0.0613 & 0.0331 & 1.8507 & 0.0660 & * \\
\hline Industry & -0.2705 & 0.0953 & -2.8380 & 0.0051 & *** \\
\hline Firm Size & -0.2563 & 0.0478 & -5.3589 & 0.0000 & $\star \star \star * *$ \\
\hline Capital Density & 0.0125 & 0.0506 & 0.2471 & 0.8051 & \\
\hline \multicolumn{6}{|c|}{ Year $=2001$} \\
\hline Constant & 1.4314 & 0.7766 & 1.8432 & 0.0671 & * \\
\hline $\begin{array}{l}\text { IT Investment } \\
\text { Ratio }\end{array}$ & 0.0649 & 0.0346 & 1.8753 & 0.0626 & * \\
\hline $\begin{array}{l}\text { Maintenance } \\
\text { Cost Ratio }\end{array}$ & 0.0552 & 0.0390 & 1.4145 & 0.1591 & \\
\hline Industry & -0.1771 & 0.1003 & -1.7657 & 0.0793 & * \\
\hline Firm Size & -0.2700 & 0.0504 & -5.3594 & 0.0000 & $\star \star \star \star *$ \\
\hline Capital Density & 0.0815 & 0.0549 & 1.4846 & 0.1396 & \\
\hline \multicolumn{6}{|c|}{ Year $=2002$} \\
\hline Constant & 1.7996 & 0.7455 & 2.4099 & 0.0171 & ** \\
\hline $\begin{array}{l}\text { IT Investment } \\
\text { Ratio }\end{array}$ & 0.0646 & 0.0359 & 1.7974 & 0.0741 & * \\
\hline $\begin{array}{l}\text { Maintenance } \\
\text { Cost Ratio }\end{array}$ & 0.0372 & 0.0410 & 0.9061 & 0.3662 & \\
\hline Industry & -0.1750 & 0.1068 & -1.6388 & 0.1032 & \\
\hline Firm Size & -0.2948 & 0.0479 & -6.1497 & 0.0000 & $\star \star \star *$ \\
\hline Capital Density & 0.0765 & 0.0539 & 1.4199 & 0.1576 & \\
\hline \multicolumn{6}{|c|}{ Year $=2003$} \\
\hline Constant & 2.0784 & 0.6852 & 3.0333 & 0.0028 & *** \\
\hline $\begin{array}{l}\text { IT Investment } \\
\text { Ratio }\end{array}$ & 0.0879 & 0.0353 & 2.4863 & 0.0139 & ** \\
\hline $\begin{array}{l}\text { Maintenance } \\
\text { Cost Ratio }\end{array}$ & 0.0154 & 0.0401 & 0.3846 & 0.7010 & \\
\hline Industry & -0.2093 & 0.1073 & -1.9511 & 0.0528 & * \\
\hline Firm Size & -0.3043 & 0.0439 & -6.9304 & 0.0000 & $\star \star \star *$ \\
\hline Capital Density & 0.0641 & 0.0551 & 1.1629 & 0.2466 & \\
\hline
\end{tabular}

Notes: ${ }^{* *} p<0.01 ;{ }^{* *} p<0.05 ;{ }^{*} p<0.1$

The sixth regression model considered OPEXP/S as the dependent variable with the same set of independent variables. The regression models representing the years
2000, 2001, 2002, and 2003 are tabulated in Table 11. The results indicate that: IT Investment Ratio and Firm Size were significant at levels of $p<0.1$ and $p<0.01$, 
The Influence of IT Investment on Business Performance/Hung. et al.

respectively, for the year 2000; IT Investment Ratio, Firm Size and Capital Density were significant at levels of $p<0.05, p<0.01$, and $p<0.05$, respectively, for both the years, 2001 and 2002; both IT Investment Ratio and Firm Size were significant at a level of $p<0.01$ for the year 2003 .

The following findings may be derived from the above analyses. ROA and IT Investment Ratio were negatively correlated; OI/S and IT Investment Ratio were positively correlated; OI/S and IT Investment Ratio were negatively correlated; both IT Investment Ratio and Firm Size were positively correlated with OI/E; OI/E, and IT Investment Ratio were negatively correlated; COGS/S and Firm Size were positively correlated; COGS/S and IT Investment Ratio were negatively correlated; SGA/S and IT Investment Ratio were positively correlated; both Industry and Firm Size were negatively correlated with SGA/S; both IT Investment Ratio and Capital Density were positively correlated with OPEXP/S; OPEXP/S and Firm Size were negatively correlated.

A $t$-test was constructed to examine the forecasting capability of all regression models.
The hypothesis was derived as follows:

$$
\begin{aligned}
& H_{0}: \mu_{y_{i}(R)}-\mu_{y_{i}(E)}=0 \\
& H_{1}: \mu_{y_{i}(R)}-\mu_{y_{i}(E)} \neq 0
\end{aligned}
$$

Where $\mu_{y_{i}(R)}$ represents the mean of real $Y_{i}$ value; $\mu_{y_{i}(E)}$ represents the mean of estimated $Y_{i}$ value; $i=1$ to 6 . The results of the hypothesis testing are listed in Table 12. We found no significant difference between the mean of real $Y_{i}$ values and the mean of estimated $Y_{i}$ values except for the following six models. For the two dependent variables $\mathrm{OI} / \mathrm{S}$ and $\mathrm{OI} / \mathrm{E}$, the difference between the forecasting value coming from the regression model and the actual value in the testing set was significant in the year 2001 at a level of $p<0.05$. For COGS/S, the difference was significant in the years 2000 and 2001, both at a level of $p<0.1$. For SGA/S, the difference was significant in the year 2000 at a level of $p<0.01$ and the years 2001 to 2003, were all at a level of $p<0.05$. For OPEXP/S, the difference was significant in the years 2000 , 2001, 2002, and 2003 at levels of $p<0.01$,

\begin{tabular}{|c|c|c|c|c|c|}
\hline \multicolumn{6}{|c|}{ Year $=2000$} \\
\hline & Coefficient & $\begin{array}{l}\text { Standard } \\
\text { Deviation }\end{array}$ & $\mathrm{t}$ value & Sig. & $\begin{array}{c}\text { Mark for } \\
\text { Significance }\end{array}$ \\
\hline Constant & 1.1548 & 0.7457 & 1.5487 & 0.1234 & \\
\hline $\begin{array}{l}\text { IT Investment } \\
\text { Ratio }\end{array}$ & 0.0786 & 0.0340 & 2.3108 & 0.0221 & * \\
\hline $\begin{array}{l}\text { Maintenance } \\
\text { Cost Ratio }\end{array}$ & 0.0296 & 0.0377 & 0.7847 & 0.4338 & \\
\hline Industry & 0.0350 & 0.0980 & 0.3573 & 0.7213 & \\
\hline Firm Size & -0.2339 & 0.0491 & -4.7603 & 0.0000 & $* * *$ \\
\hline Capital Density & 0.0247 & 0.0520 & 0.4757 & 0.6349 & \\
\hline \multicolumn{6}{|c|}{ Year= 2001} \\
\hline Constant & 0.9718 & 0.7998 & 1.2150 & 0.2261 & \\
\hline $\begin{array}{l}\text { IT Investment } \\
\text { Ratio }\end{array}$ & 0.0842 & 0.0356 & 2.3631 & 0.0193 & $* *$ \\
\hline
\end{tabular}
$p<0.1, p<0.05$, and $p<0.05$, respectively. 
The Influence of IT Investment on Business Performance/ Hung. et al.

\begin{tabular}{|c|c|c|c|c|c|}
\hline $\begin{array}{l}\text { Maintenance } \\
\text { Cost Ratio }\end{array}$ & 0.0423 & 0.0402 & 1.0540 & 0.2935 & \\
\hline Industry & 0.1460 & 0.1033 & 1.4135 & 0.1594 & \\
\hline Firm Size & -0.2393 & 0.0519 & -4.6115 & 0.0000 & $* * *$ \\
\hline Capital Density & 0.1180 & 0.0566 & 2.0850 & 0.0386 & $* *$ \\
\hline \multicolumn{6}{|c|}{ Year $=2002$} \\
\hline Constant & 1.2349 & 0.7750 & 1.5934 & 0.1130 & \\
\hline $\begin{array}{l}\text { IT Investment } \\
\text { Ratio }\end{array}$ & 0.0806 & 0.0374 & 2.1585 & 0.0324 & $* *$ \\
\hline $\begin{array}{l}\text { Maintenance } \\
\text { Cost Ratio }\end{array}$ & 0.0234 & 0.0427 & 0.5481 & 0.5844 & \\
\hline Industry & 0.1764 & 0.1110 & 1.5894 & 0.1139 & \\
\hline Firm Size & -0.2582 & 0.0498 & -5.1811 & 0.0000 & $* * *$ \\
\hline Capital Density & 0.1147 & 0.0560 & 2.0485 & 0.0421 & $* *$ \\
\hline \multicolumn{6}{|c|}{ Year $=2003$} \\
\hline Constant & 1.6415 & 0.7313 & 2.2445 & 0.0262 & $* *$ \\
\hline $\begin{array}{l}\text { IT Investment } \\
\text { Ratio }\end{array}$ & 0.1033 & 0.0377 & 2.7388 & 0.0069 & $* * *$ \\
\hline $\begin{array}{l}\text { Maintenance } \\
\text { Cost Ratio }\end{array}$ & 0.0032 & 0.0429 & 0.0750 & 0.9403 & \\
\hline Industry & 0.1754 & 0.1145 & 1.5316 & 0.1276 & \\
\hline Firm Size & -0.2746 & 0.0469 & -5.8592 & 0.0000 & $* * *$ \\
\hline Capital Density & 0.0951 & 0.0588 & 1.6167 & 0.1079 & \\
\hline
\end{tabular}

Notes: ${ }^{* * *} p<0.01 ;{ }^{* *} p<0.05 ;{ }^{*} p<0.1$

\section{Table 12 - $t$-test for the performance of regression models.}

Return on Assets (ROA)

\begin{tabular}{|l|c|c|c|c|c|}
\hline \multicolumn{1}{|c|}{ Year } & $\mu_{\mathrm{yi}(\mathrm{R})}-\mu_{\mathrm{yi}(\mathrm{E})}$ & $\begin{array}{c}\text { Standard } \\
\text { Deviation }\end{array}$ & $t$ value & Sig. & $\begin{array}{c}\text { Mark for } \\
\text { Significance }\end{array}$ \\
\hline 2000 & -0.0069 & 1.3309 & -0.0478 & 0.9620 & \\
\hline 2001 & -0.2158 & 1.5529 & -0.2736 & 0.2064 & \\
\hline 2002 & 0.0452 & 1.5804 & 0.2622 & 0.7938 & \\
\hline 2003 & 0.0730 & 1.5177 & 0.4410 & 0.6604 & \\
\hline \multicolumn{7}{|l|}{ Operating Income to Sales Ratio (OI/S) } \\
\hline 2000 & 0.1474 & 1.5092 & 0.8949 & 0.3734 & \\
\hline 2001 & 0.4566 & 1.6479 & 2.5397 & 0.0130 & $* *$ \\
\hline 2002 & -0.0049 & 1.6873 & -0.0264 & 0.9790 & \\
\hline 2003 & -0.2038 & 1.4912 & -1.2528 & 0.2138 & \\
\hline Operating Income to Employees Ratio (OI/E) \\
\hline 2000 & 0.5233 & 4.3448 & 1.1038 & 0.2729 & \\
\hline
\end{tabular}




\begin{tabular}{|c|c|c|c|c|c|}
\hline 2001 & 1.2300 & 4.9483 & 2.2782 & 0.0253 & ** \\
\hline 2002 & -0.0365 & 4.5641 & -0.0733 & 0.9417 & \\
\hline 2003 & -0.7705 & 4.5749 & -1.5436 & 0.1265 & \\
\hline \multicolumn{6}{|c|}{ Cost of Goods Sold to Sales (COGS/S) } \\
\hline 2000 & -0.0409 & 0.2210 & -1.6944 & 0.0939 & * \\
\hline 2001 & -0.0468 & 0.2216 & -1.9368 & 0.0562 & * \\
\hline 2002 & -0.0258 & 0.2087 & -1.1345 & 0.2599 & \\
\hline 2003 & -0.0104 & 0.1977 & -0.4840 & 0.6297 & \\
\hline \multicolumn{6}{|c|}{ Selling and General Administrative Expenses to Sales (SGA/S) } \\
\hline 2000 & 0.1743 & 0.5964 & 2.6792 & 0.0089 & *** \\
\hline 2001 & 0.1435 & 0.5703 & 2.3063 & 0.0236 & ** \\
\hline 2002 & 0.1882 & 0.6521 & 2.6456 & 0.0098 & ** \\
\hline 2003 & 0.1629 & 0.6724 & 2.2196 & 0.0292 & ** \\
\hline \multicolumn{6}{|c|}{ Total Operating Expenses to Sales (OPEXP/S) } \\
\hline 2000 & 0.1699 & 0.5776 & 2.6964 & 0.0085 & *** \\
\hline 2001 & 0.1136 & 0.5707 & 1.8236 & 0.0718 & * \\
\hline 2002 & 0.1569 & 0.6457 & 2.2274 & 0.0286 & ** \\
\hline 2003 & 0.1482 & 0.6663 & 2.0383 & 0.0447 & ** \\
\hline
\end{tabular}

Notes: ${ }^{* *} p<0.01 ;{ }^{* *} p<0.05 ;{ }^{*} p<0.1$

\section{Moderation Analysis}

Two categorical variables (Industry and Firm Size) in the independent variable set are possible candidates for further insights regarding the inter-category variations. We re-analyzed the above regressions by considering the moderation effect of Industry and Firm Size. It was not statistically significant for all dependent variables in all years except in cases where the dependent variable was COGS/S and moderator was Firm Size. The moderating effect of Industry is not statistically significant for all dependent variables in all years.

In year 2000, the moderating effect of Firm Size was significant (at 0.05 level) for Industry $(b=-.108, \quad p=.020), \quad$ IT Investment Ratio $(b=-.041, \quad p=.022)$ and Capital Density $(b=-.117, p=.000)$. This moderating effect changed to only Maintenance Cost Ratio $(b=.036, p=0.032)$ in year 2001 and reverted back to only IT Investment Ratio $(b=-.050$, $p=0.019$ ) in year 2002. In year 2003, it was also on IT Investment Ratio ( $b=-.042, p=.046)$. Judging by the above result, Firm Size seems to moderate IT Investment Ratio across most years. Although this is quite consistent with existing findings in the literature, we would like to offer two additional observations. First, the aforementioned moderating effect of Firm Size on IT Investment Ratio was only found when the dependent variable was COGS/S. In other words, IT investment ratios vary across different sizes of firms when predicting COGS/S. Second, the statistical significance does not always lead to enough implications when practical significance is also considered. The magnitude of such a moderating effect is quite small as shown in the beta coefficients. One is cautioned when interpreting the results based solely on statistical significance.

\section{Results from BPN Models}

The first BPN model considered ROA as the output neuron, using IT Investment Ratio, Maintenance Cost Ratio, Industry, Firm Size, 
The Influence of IT Investment on Business Performance/ Hung. et al.

and Capital Density as input neurons. This study derived BPN models for the years 2000 , 2001, 2002, and 2003 at a minimum error of $0.01445,0.02200,0.02206$, and 0.01615 , respectively. The first type of BPN models explained $29.75 \%, 11.65 \%, 21.20 \%$, and $5.45 \%$ of the variance of ROA for the years $2000,2001,2002$, and 2003, respectively.

The second BPN model considered OI/S as the output neuron, using the same set of independent variables as input neurons. This study derived BPN models for the years 2000 , 2001, 2002, and 2003 at a minimum error of $0.01893,0.01945,0.01532$, and 0.00872 , respectively. The second type of BPN models explained $18.08 \%, 12.20 \%, 12.31 \%$, and $21.74 \%$ of the variance of Ol/S for the years $2000,2001,2002$, and 2003, respectively.

The third BPN model considered OI/E as the output neuron, using the same set of independent variables as input neurons. This study derived BPN models for the years 2000 , 2001, 2002, and 2003 at a minimum error of $0.02550,0.04180,0.02204$, and 0.00884, respectively. The third type of BPN model explained $8.18 \%, 7.73 \%, 24.79 \%$, and $37.36 \%$ of the variance of OI/E for the years $2000,2001,2002$, and 2003, respectively.

The fourth BPN model considered COGS/S as the output neuron, using the same set of independent variables as input neurons. This study derived BPN models for the years 2000 , 2001, 2002, and 2003 at a minimum error of $0.00076,0.00049,0.00049$, and 0.00046, respectively. The fourth type of BPN models explained $71.23 \%, 68.95 \%, 63.90 \%$, and $61.23 \%$ of the variance of COGS/S for the years 2000, 2001, 2002, and 2003, respectively.

The fifth BPN model considered SGA/S as the output neuron, using the same set of independent variables as input neurons. This study derived BPN models for the years 2000 , 2001, 2002, and 2003 at a minimum error of $0.01124,0.01175,0.01234$, and 0.00647 , respectively. The fifth type of BPN models explained $23.50 \%, 23.37 \%, 26.96 \%$, and $39.19 \%$ of the variance of SGA/S for the years $2000,2001,2002$, and 2003, respectively.

The sixth BPN model considered OPEXP/S as the output neuron, using the same set of independent variables as input neurons. This study derived BPN models for the years 2000 , 2001, 2002, and 2003 at a minimum error of $0.01376,0.01354,0.01274$, and 0.00739 , respectively. The sixth type of BPN models explained $19.20 \%, 21.11 \%, 21.72 \%$, and $36.06 \%$ of the variance of OPEXP/S for the years 2000, 2001, 2002, and 2003, respectively.

As with the analysis of the regression model, we conducted a $t$-test to examine the forecasting capability of all BPN models. The results of the hypothesis testing are listed in Table 13. We found no significant difference between the mean of real $Y_{i}$ values and the mean of estimated $Y_{i}$ values except for the following six models. For OI/E, the difference between the forecasted value coming from the BPN model and the actual value in the testing set was significant in the year 2000 at a level of $p<0.1$. For COGS/S, the difference between was significant in the years 2000 and 2001 at levels of $p<0.05$ and $p<0.01$, respectively. For SGA/S, the difference was significant in the years 2001 and 2002, both at a level of $p<0.1$. For OPEXP/S, the difference between the forecasted value from the BPN model and the actual value in the testing set was significant in the year 2001 at a level of $p<0.1$. 


\begin{tabular}{|c|c|c|c|c|c|}
\hline \multicolumn{6}{|c|}{ Return on Assets (ROA) } \\
\hline Year & $\mu_{\mathrm{yi}(R)}-\mu_{\mathrm{yi}(E)}$ & $\begin{array}{l}\text { Standard } \\
\text { Deviation }\end{array}$ & $t$ value & Sig. & $\begin{array}{c}\text { Mark for } \\
\text { Significance }\end{array}$ \\
\hline 2000 & -0.0737 & 1.3273 & -0.5090 & 0.6121 & \\
\hline 2001 & -0.0172 & 1.5343 & -0.1025 & 0.9186 & \\
\hline 2002 & 0.1516 & 1.5222 & 0.9128 & 0.3640 & \\
\hline 2003 & 0.1393 & 1.5168 & 0.8415 & 0.4025 & \\
\hline \multicolumn{6}{|c|}{ Operating Income to Sales Ratio (OI/S) } \\
\hline 2000 & -0.0456 & 1.5071 & -0.2771 & 0.7842 & \\
\hline 2001 & 0.2337 & 1.6324 & 1.3123 & 0.1930 & \\
\hline 2002 & 0.0084 & 1.6789 & 0.0457 & 0.9637 & \\
\hline 2003 & -0.0673 & 1.4709 & -0.4191 & 0.6762 & \\
\hline \multicolumn{6}{|c|}{ Operating Income to Employees Ratio (OI/E) } \\
\hline 2000 & -0.9008 & 4.3526 & -1.8968 & 0.0613 & * \\
\hline 2001 & -0.2403 & 4.8826 & -0.4511 & 0.6531 & \\
\hline 2002 & -0.4515 & 4.5350 & -0.9124 & 0.3642 & \\
\hline 2003 & -0.6354 & 4.4875 & -1.2978 & 0.1980 & \\
\hline \multicolumn{6}{|c|}{ Cost of Goods Sold to Sales (COGS/S) } \\
\hline 2000 & -0.0593 & 0.2073 & -2.6202 & 0.0104 & ** \\
\hline 2001 & -0.0668 & 0.2101 & -2.9155 & 0.0046 & $\star * \star *$ \\
\hline 2002 & -0.0175 & 0.2069 & -0.7748 & 0.4406 & \\
\hline 2003 & -0.0065 & 0.1989 & -0.2989 & 0.7658 & \\
\hline \multicolumn{6}{|c|}{ Selling and General Administrative Expenses to Sales (SGA/S) } \\
\hline 2000 & 0.0733 & 0.6006 & 1.1192 & 0.2663 & \\
\hline 2001 & 0.1125 & 0.5676 & 1.8170 & 0.0728 & * \\
\hline 2002 & 0.1179 & 0.6474 & 1.6692 & 0.0989 & * \\
\hline 2003 & 0.0827 & 0.6672 & 1.1361 & 0.2592 & \\
\hline \multicolumn{6}{|c|}{ Total Operating Expenses to Sales (OPEXP/S) } \\
\hline 2000 & 0.0878 & 0.5678 & 1.3947 & 0.1668 & \\
\hline 2001 & 0.1051 & 0.5647 & 1.7052 & 0.0919 & * \\
\hline 2002 & 0.0539 & 0.6420 & 0.7699 & 0.4436 & \\
\hline 2003 & 0.0174 & 0.6617 & 0.2404 & 0.8106 & \\
\hline
\end{tabular}

Notes: ${ }^{* *} p<0.01 ;{ }^{* *} p<0.05 ;{ }^{*} p<0.1$

\section{Comparison between Regression Models and BPN Models}

To justify the performance of both regression models and BPN models, we conducted a $t$-test to examine the difference between real values and estimated values. We then employed the values of R-square, RMSE, and
MAE to compare the performance of the regression models and the BPN models. The larger the R-square value of a model is, the better the forecasting capability of it. For the values of RMSE and MAE, the smaller the values of a model are, the better the forecasting capability of it. 
The Influence of IT Investment on Business Performance/ Hung. et al.

For the dependent variable of ROA, the performance of both regression models and BPN models was promising, because there was no significant difference between the real values and the estimated values. For the dependent variable of $\mathrm{OI} / \mathrm{S}$, the performance of the BPN models was good, because there was no significant difference between the real values and the estimated ones. However, the performance of the regression models was not as good, because there was a significant difference between the real values and the estimated ones for the year 2001 at the significance level of $p<0.05(t=2.5397)$.

For the dependent variable of $\mathrm{Ol} / \mathrm{E}$, the performance of both the regression models and the BPN models was not particularly good, because there was a significant difference between the real values and estimated ones such as for the BPN model in 2000 and the regression model in 2001. For the dependent variable of COGS/S, the performance of both BPN models and regression models was not so good, because there was a significant difference between the real values and the estimated ones for both the BPN models and the regression models in the years 2001 and 2002.

For the dependent variable SGA/S, the performance of both regression models and BPN models was not satisfactory, because there was a significant difference between the real values and the estimated ones for the
BPN models in the years 2001 and 2002 and the regression models for all four years (from 2000 to 2003). For the dependent variable OPEXP/S, the results of both BPN models and regression models was inferior, because there was a significant difference between the real values and the estimated ones for the BPN model in 2001 and the regression models for all four years.

The results of comparing regression models with BPN models for all dependent variables are tabulated in Table 14. The average R-Square, RMSE, and MAE using the regression model are $0.1636,1.5355$, and 1.1962, respectively, whereas all three measures using the BPN model are 0.2796, 1.5106 , and 1.0732, respectively. We applied the paired t-tests to examine the differences between the regression models and the BPN models. The results indicate that the mean differences of all three measures between the regression and the BPN models are statistically significant at the significance level of $p<0.05$ (i.e., R-Square: $t=-2.940, p<0.01$, RMSE: $t=2.453, p<0.05$, MAE: $t=2.629$, $p<0.05)$.It can be concluded that the performance of the BPN models is better than the performance of the regression models for the variables of ROA, OI/S, OI/E, COGS/S, and OPEXP/S. Only the variable SGA/S, showed results in which the performance of the BPN models was better than that of the regression ones in the years of 2001, 2002, and 2003.

\begin{tabular}{|c|c|c|c|c|c|}
\hline \multicolumn{6}{|c|}{ Return on Assets (ROA) } \\
\hline & & 2000 & 2001 & 2002 & 2003 \\
\hline \multirow[t]{2}{*}{ R-Square } & Regression & 0.2605 & 0.1027 & 0.0732 & 0.0496 \\
\hline & BPN & 0.2975 & 0.1165 & 0.2120 & 0.0545 \\
\hline \multirow[t]{2}{*}{ RMSE } & Regression & 1.3229 & 1.5586 & 1.5716 & 1.5104 \\
\hline & BPN & 1.3214 & 1.5253 & 1.5207 & 1.5141 \\
\hline \multirow[t]{2}{*}{ MAE } & Regression & 1.0283 & 1.2694 & 1.2689 & 1.1449 \\
\hline & BPN & 1.0241 & 1.1654 & 1.2197 & 1.1666 \\
\hline \multicolumn{6}{|c|}{ Operating Income to Sales Ratio (OI/S) } \\
\hline & & 2000 & 2001 & 2002 & 2003 \\
\hline R-Square & Regression & 0.1662 & 0.1135 & 0.1292 & 0.0932 \\
\hline
\end{tabular}




\begin{tabular}{|c|c|c|c|c|c|}
\hline & BPN & 0.01808 & 0.1220 & 0.1231 & 0.2174 \\
\hline \multirow[t]{2}{*}{ RMSE } & Regression & 1.5074 & 1.7005 & 1.6772 & 1.4963 \\
\hline & BPN & 1.4988 & 1.6394 & 1.6689 & 1.4637 \\
\hline \multirow[t]{2}{*}{ MAE } & Regression & 1.2012 & 1.4029 & 1.3086 & 1.0796 \\
\hline & BPN & 1.1554 & 1.3091 & 1.3049 & 1.0689 \\
\hline \multicolumn{6}{|c|}{ Operating Income to Employees Ratio (OI/E) } \\
\hline & & 2000 & 2001 & 2002 & 2003 \\
\hline \multirow[t]{2}{*}{ R-Square } & Regression & 0.0802 & 0.0705 & 0.1409 & 0.1104 \\
\hline & $\mathrm{BPN}$ & 0.0818 & 0.0773 & 0.2479 & 0.3736 \\
\hline \multirow[t]{2}{*}{ RMSE } & Regression & 4.3505 & 5.0702 & 4.5370 & 4.6124 \\
\hline & BPN & 4.4194 & 4.8594 & 4.5305 & 4.5058 \\
\hline \multirow[t]{2}{*}{ MAE } & Regression & 3.4015 & 4.4236 & 3.3273 & 3.1779 \\
\hline & BPN & 2.7282 & 3.5557 & 2.9549 & 2.8600 \\
\hline \multicolumn{6}{|c|}{ Cost of Goods Sold to Sales (COGS/S) } \\
\hline & & 2000 & 2001 & 2002 & 2003 \\
\hline \multirow[t]{2}{*}{ R-Square } & Regression & 0.2100 & 0.1746 & 0.1307 & 0.1131 \\
\hline & BPN & 0.7123 & 0.6895 & 0.6390 & 0.6123 \\
\hline \multirow[t]{2}{*}{ RMSE } & Regression & 0.2235 & 0.2252 & 0.2090 & 0.1968 \\
\hline & BPN & 0.2144 & 0.2193 & 0.2065 & 0.1978 \\
\hline \multirow[t]{2}{*}{ MAE } & Regression & 0.1393 & 0.1444 & 0.1267 & 0.1199 \\
\hline & BPN & 0.1146 & 0.1217 & 0.1182 & 0.1228 \\
\hline \multicolumn{6}{|c|}{ Selling and General Administrative Expenses to Sales (SGA/S) } \\
\hline & & 2000 & 2001 & 2002 & 2003 \\
\hline \multirow[t]{2}{*}{ R-Square } & Regression & 0.2368 & 0.2272 & 0.2571 & 0.3121 \\
\hline & BPN & 0.2350 & 0.2337 & 0.2696 & 0.3919 \\
\hline \multirow[t]{2}{*}{ RMSE } & Regression & 0.6180 & 0.5848 & 0.6750 & 0.6880 \\
\hline & BPN & 0.6015 & 0.5753 & 0.6543 & 0.6684 \\
\hline \multirow[t]{2}{*}{ MAE } & Regression & 0.4627 & 0.4397 & 0.8036 & 0.5156 \\
\hline & BPN & 0.4640 & 0.4288 & 0.4897 & 0.5081 \\
\hline \multicolumn{6}{|c|}{ Total Operating Expenses to Sales (OPEXP/S) } \\
\hline & & 2000 & 2001 & 2002 & 2003 \\
\hline \multirow[t]{2}{*}{ R-Square } & Regression & 0.1920 & 0.2055 & 0.2163 & 0.2619 \\
\hline & BPN & 0.1954 & 0.2111 & 0.2172 & 0.3606 \\
\hline \multirow[t]{2}{*}{ RMSE } & Regression & 0.5988 & 0.5785 & 0.6608 & 0.6787 \\
\hline & BPN & 0.5800 & 0.5711 & 0.6404 & 0.6579 \\
\hline \multirow[t]{2}{*}{ MAE } & Regression & 0.4626 & 0.4457 & 0.4870 & 0.5286 \\
\hline & BPN & 0.4524 & 0.4331 & 0.4755 & 0.5159 \\
\hline
\end{tabular}

\section{Conclusions and Managerial Implications}

The rapid development of IT has led firms to leverage the possible benefits of IT to enhance business performance. However, the "IT productivity paradox" has caused some firms to look more seriously into the possible benefits that may be derived from an IT investment. Although a number of scholars 
The Influence of IT Investment on Business Performance/ Hung. et al.

(Loveman, 1994; Roach, 1988; Strassmann, 1990) have pointed out that over-investment in IT may hinder or reduce productivity, other researchers (McFarlane, 1984; Porter and Millar, 1985) have supported the notion that IT can be the key to gaining a competitive advantage. Therefore, this study explored the relationship between IT investment and business performance using longitudinal data from public financial reports.

In the canonical correlation, the first function includes the canonical varieties that explain the largest proportion of variance. In our case, the largest variance happened when correlating $\mathrm{OI} / \mathrm{E}$ with the independent variables for each year after year one. The remaining canonical functions explain the variance of the relationship between other dependent variables and the independent variables.

The role of IT investment in firm performance is quite complex. Our canonical correlation analysis shows that IT investment was a strong predictor in all functions. In the first, its effect was more on OI/E (a profit effectiveness variable), while on OPEXP/S, OI/S, OI/E and COGS/S in the second canonical function. Since the above dependent variables fall in both profit effectiveness and cost efficiency categories as we discussed before, it shows that IT investment is not just associated with cost reduction as reported predominantly (or casually) in anecdotal reports. In fact, the largest variance in our canonical correlation analysis was explained for Operating Income to Employees Ratio (Ol/E), a profit effectiveness variable. Therefore, managers are recommended to take a broader view towards the effect of IT investment.

Although both the BPN and the regression models show that IT investment has an effect on the performance indicators individually, the effect is not uniformly the same across all performance indicators for all years. However, an interesting pattern emerges if one examines tables 6 through 11. IT investment is certainly a predictor for OI/S, OI/E, COGS/S, SGA/S and OPEXP/S not necessarily for year one, but definitely for most years following.
This provides some basic evidence for a time lag. It is interesting to see that IT investment has little influence on ROA. One possible explanation is that firms may consider investment in IT as an expense rather than an asset. Therefore, it is reasonable to see no significant relationship between IT investment and ROA.

Another interesting finding is that the Maintenance Cost Ratio has a negative impact on ROA, OI/S, and Ol/E. The aforementioned implies that high maintenance costs may be a symbol or a warning sign of operational inefficiency, eventually leading to reduced business performance. This is a reminder that firms have to pay attention to control maintenance costs as well as to the benefits of IT. We found that the larger a company is, the lower the SGA/S and OPEXP/S are. This implies that IT can help firms to take advantage of the scale of the economy.

Brynjolfsson (1993) argued that IT investment requires 2 to 3 years to demonstrate performance. This is the so-called "time-lag effect," which is supported to a certain degree by this study. For OI/S, OI/E, SGA/S, and OPEXP/S, the BPN models explain the variance of the above four variables most effectively for the year 2003. This indicates that IT investment in 2000 required 3 years to generate performance, which supports the argument of the time-lag effect. In the time period of this study, many firms devoted considerable capital to solving the $\mathrm{Y} 2 \mathrm{~K}$ problem prior to 2000 . It may be found that the financial ratios as dependent variables did not improve until 2003. This finding may explain why the time-lag effect exists in this study.

Additionally the moderation analysis that uses two independent variables, Industry and Firm Size, as the moderators has generated some insights. Although we would expect the performance prediction to vary across industries, Industry was not found to be a statistically significant moderator for all years. While this holds true, Firm Size did have some limited moderating effect on models 
involving COGS as the dependent variable. In year one (year 2000), Firm Size had a moderating effect on Industry, IT Investment Ratio and Capital Density. This effect diminishes to only Maintenance Cost Ratio in year two, and IT Investment Ratio in years three and four. Although statistically significant, the magnitude of these moderating effects have been quite minimal $(|b|=.050$ or less) after year one. This becomes a case of statistical significance with minimal practical significance. With the absence of strong moderation, a focus on the main effects seems reasonable.

In addition to the above managerial implications, this study also provides a contribution for academics. By comparing the regression models with the BPN models, we found that the forecasting ANN (especially BPN) models are better than the regression models in examining the relationship between IT investment and other measures due to their theoretical support for non-linear relationships among variables. In our work, this is confirmed for all four years, which captures a small scale of the longitudinal trend with the four years data. To put it differently, non-linearity of variable relationships not only applies to year one where initial investment was assumed, it also applies to the subsequent years where the time lag effect was also present.

\section{References}

Ali Bazaee, G. (2010). "Effects of Information Technology Investment on Organizational Performance in India and Iran: An Empirical Study," International Journal of Management, 27(1), pp. 76-82.

Awodele, O. and Jegede, O. (2009). "Neural networks and its application in engineering." Informing Science \& IT Education Conference, Macon, GA, USA.

Barua, A., Kriebel, C. H., and Mukhopadhyay, T. (1995). "Information technologies and business value: An analytic and empirical investigation," Information systems research, 6(1), pp. 3-23.

Bharadwaj, A. S. (2000). "A resource-based perspective on information technology capability and firm performance: an empirical investigation," MIS quarterly, 24(1), pp. 169-196.

Bodyanskiy, Y. and Popov, S. (2006). "Neural network approach to forecasting of quasiperiodic financial time series," European Journal of Operational Research, 175(3), pp. 1357-1366.

Bresnahan, T. F., Brynjolfsson, E., and Hitt, L. M. (2002). "Information technology, workplace organization, and the demand for skilled labor: firm-level evidence," Quarterly Journal of Economics, 117(1), pp. 339-376.

Brynjolfsson, E. (1993). "The productivity paradox of information technology," Communications of the ACM, 36(12), pp. 66-77.

Brynjolfsson, E. and Hitt, L. (1996). "Paradox lost? Firm-level evidence on the returns to information systems spending," Management science, 42(4), pp. 541-558.

Brynjolfsson, E. and Hitt, L. M. (1998). "Beyond the productivity paradox," Communications of the ACM, 41(8), pp. 49-55.

Brynjolfsson, E. and Hitt, L. M. (1993). "Is Information Systems Spending Productive? New Evidence and New Results," Proceedings of the Fourteenth International Conference on Information Systems, Orlando, Florida, USA.

Brynjolfsson, E. and Yang, S. (1997). "The intangible benefits and costs of investments: evidence from financial markets," Proceedings of the eighteenth international conference on Information systems, Altanta, Georgia. 
The Influence of IT Investment on Business Performance/ Hung. et al.

Campbell M. (2012). "What a Difference a Year Makes: Time Lag Effect of Information Technology Investment on Firm Performance,"Journal of Organizational Computing and Electronic Commerce, 22(3), pp.237-255.

Cash, J. I. and Konsynski, B. R. (1985). "IS redraws competitive boundaries," Harvard Business Review, 63, pp. 134-142.

Chang, I.C., Hwang, H. G., Liaw, H. C., Hung, M. C., Chen, S. L., and Yen, D. C. (2008). "A neural network evaluation model for ERP performance from SCM perspective to enhance enterprise competitive advantage," Expert systems with applications, 35(4), pp. 1809-1816.

Chi, L. C. and Tang, T. C. (2005). "Artificial neural networks in reorganization outcome and investment of distressed firms: the Taiwanese case," Expert Systems with Applications, 29(3), pp. 641-652.

Dale Stoel, M. and Muhanna, W.A. (2009). "IT capabilities and firm performance: a contingencyanalysis of the role of industry and IT capability type," Information \& Management,46(3), pp. 181-189.

Davies, P. (1994). "Design issues in neural network development," Neurovest Journal, 5(1), pp. 21-25.

Dehning, B. and Richardson, V. J. (2002). "Returns on investments in information technology: A research synthesis," Journal of Information Systems, 16(1), pp. 7-30.

Devaraj, S. and Kohli, R. (2000). "Information technology payoff in the health-care industry: a longitudinal study," Journal of Management Information Systems,16(4), pp. 41-67.

Devaraj, S. and Kohli, R. (2003). "Performance impacts of information technology: Is actual usage the missing link?," Management science, 49(3), pp. 273-289.

Eid, A. G. (2010). "Information technology, productivity, value added, and inflation: An empirical study on the U.S. economy, 1959-2008," Journal of Applied Business and Economics, 11(1), pp. 133-153.

Etzioni, A. (1964). Modern Organizations. Englewood Cliffs, NJ: Prentice-Hall.

Girma, S., Greenaway, D., and Wakelin, K. (2001). "Who benefits from foreign direct investment in the UK?," Scottish Journal of Political Economy, 48(2), pp. 119-133.

Grant, F. R. (1991). "The Resource-Based Theory of Competitive Advantage: Implications for Strategy," California Management Review, 33(3), pp. 114-135.

Grinyer, P. H. and Norburn, D. (1975). "Planning for existing markets: Perceptions of executives and financial performance," Journal of the Royal Statistical Society. Series A (General), 138(1), pp. 70-97.

Harris, S.E. and Katz, J.L. (1989). "Differentiating Organizational Performance Using Information Technology Managerial Control Ratios in the Insurance Industry,"Information Technology \& People, 5(4), 275-297.

Hitt, L. M. and Brynjolfsson, E. (1996). "Productivity, Business Profitability, and Consumer Surplus: Three Different Measures of Information Technology Value," MIS Quarterly, 20(2), pp. 121-143.

Ho, S. and Mallick, S. (2009). "The impact of information technology on the banking industry," Journal of the Operational Research Society, 61(2), pp. 211-221. 
Huang, S. M., Ou, C. S., Chen, C. M., and Lin, B. (2006). "An empirical study of relationship between IT investment and firm performance: A resource-based perspective," European Journal of Operational Research, 173(3), pp. 984-999.

Hung C.S., Yen,D.C., and Ou C.S., (2012) "An empirical study of the relationship between a self-service technology investment and firm financial performance,"Journal of Engineering and Technology Management, 29(1), pp. 62-70.

Jorgenson, D. W. and Stiroh, K. J. (1999). "Information technology and growth," The American Economic Review, 89(2), pp. 109-115.

Jorgenson, D. W. and Stiroh, K. J. (2000). "Raising the speed limit: US economic growth in the information age," Brookings papers on economic activity, 2000(1), pp. 125-210.

Joshi, K. and Pant, S. (2008). "Development of a framework to assess and guide IT investments: An analysis based on a discretionary? andatory classification," International Journal of Information Management, 28(3), pp. 181-193.

Kim, J. K., Xiang, J. Y., and Lee, S. (2009). "The impact of IT investment on firm performance in China: An empirical investigation of the Chinese electronics industry," Technological Forecasting and Social Change, 76(5), pp. 678-687.

King, W. R. and Grover, V. (1991). "The strategic use of information resources: an exploratory study," IEEE Transactions on Engineering Management, 38(4), pp. 293-305.

Kohli, R., and Devaraj, S. (2004). "Realizing the business value of information technology investments: an organizational process," MIS Quarterly, 3(1), pp. 53-68.
Laudon, K. C. and Laudon, J. P. (2006). Management Information Systems: Managing the Digital Firm $\left(10^{\text {th }} \mathrm{ed}\right)$, Prentice-Hall: New Jersey, USA.

Liang, T.-P., You, J.-J., and Liu, C.-C., (2010). "A resource-based Perspective on Information Technology and Firm Performance: A Meta Analysis," Industrial Management \& Data Systems, 110(8), pp. 1138-1158.

Lim,J.-H., Dehning, B., Richardson, V. J., and Smith R. E. (2011). "A Meta-Analysis of the Effects of IT Investment on Firm Financial Performance," Journal of Information Systems, 25(2), pp. 145-169.

Loveman, G. W. (1994). An assessment of the productivity impact of information technologies, Oxford University Press: New York.

Mata, F. J., Fuerst, W. L., and Barney, J. B. (1995). "Information technology and sustained competitive advantage: A resource-based analysis," MIS quarterly,19(4), pp. 487-505.

Matusik, S. F. and Hill, C. W. L. (1998). "The utilization of contingent work, knowledge creation, and competitive advantage," Academy of management review,23(4), pp. 680-697.

McAfee, A. (2002). "The impact of enterprise information technology adoption on operational performance: an empirical investigation," Production and Operations Management, 11(1), pp. 33-53.

McClelland, J. L. and Rumelhart, D. E. (1989). Explorations in Parallel Distributed Processing-Macintosh Version: A Handbook of Models, Programs, and Exercises, MIT press: Cambridge, MA, USA.

McCulloch, W. S. and Pitts, W. (1990). "A logical calculus of the ideas immanent in nervous activity," Bulletin of 
The Influence of IT Investment on Business Performance/ Hung. et al.

mathematical biology, 52(1), pp. 99-115.

McFarlane, F. W. (1984). "Information technology changes the way you compete," Harvard Business Review, 62, pp. 98-103.

McKeen, J. D. and Smith, H. A. (1993) "The relationship between information technology use and organizational performance", in Strategic information technology management, Hershey, PA, USA: IGI Publishing.

Melville, N., Kraemer, K., and Gurbaxani, V. (2004). "Review: Information technology and organizational performance: An integrative model of IT business value," MIS quarterly, 28(2), pp. 283-322.

Mitra, S. and Chaya, A. K. (1996). "Analyzing cost-effectiveness of organizations: the impact of information technology spending," Journal of Management Information Systems, 13(2), pp. 29-57.

Nam, K. and Schaefer, T. (1995). "Forecasting international airline passenger traffic using neural networks," Logistics and Transportation Review, 31(3), pp. 239-251.

O'Brien, J. A. (1995). Introduction to Information Systems: An End User/Enterprise Perspective, Richard D Irwin: Chicago.

Oliner, S. D. and Sichel, D. E. (2000). "The resurgence of growth in the late 1990s: is information technology the story?," The Journal of Economic Perspectives, 14(4), pp. 3-22.

Ong,C.-S., Chen,P.-Y. (2013). "Information technology capability-enabled performance, future performance, and value," Industrial Management \& Data Systems, 113(5).

Osei-Bryson, K. M. and Ko, M. (2004). "Exploring the relationship between information technology investments and firm performance using regression splines analysis," Information \& management, 42(1), pp. 1-13.

Pao, H. T. (2008). "A comparison of neural network and multiple regression analysis in modeling capital structure," Expert Systems with Applications, 35(3), pp. 720-727.

Porter, M. and Millar, V. (1985). "How information gives your competitive advantage," Harvard Business Review, 49 , pp. $149-160$.

Rai, A., Patnayakuni, R., and Patnayakuni, N. (1997). "Technology investment and business performance," Communications of the ACM, 40(7), pp. 89-97.

Ravichandran, T. and Lertwongsatien, C. (2005). "Effect of information systems resources and capabilities on firm performance: A resource-based perspective," Journal of Management Information Systems, 21(4), pp. 237-276.

Ravichandran, T., Liu, Y., Han, S. and Hasan, I. (2009). "Diversification and firm performance:exploring the moderating effects of information technology spending," Journal ofManagement Information Systems, 25(4), pp. 205-240.

Ringwood, J. and Galvin, G. (2002). "Computer-aided learning in artificial neural networks," IEEE Transactions on Education, 45(4), pp. 380-387.

Roach, S. S. (1988). "Technology and the services sector: the hidden competitive challenge," Technological Forecasting and Social Change, 34(4), pp. 387-403.

Robson, W. (1997). Strategic Management and Information Systems: An Integrated Approach, Financial Times/ Prentice Hall: Harlow, Essex. 
The Influence of IT Investment on Business Performance/Hung. et al.

Ross, J. W., Beath, C. M., and Goodhue, D. L. (1996). "Develop long-term competitiveness through IT assets," Sloan management review, 38(1), pp. 31-42.

Rumelhart, D. E., Hinton, G. E., and Williams, R. J. (1986) "Learning internal representations by error propagation", in E. R. David, L. M. James, and C. P. R. Group (Eds.) Parallel distributed processing: explorations in the microstructure of cognition: MIT Press.

Sabzevari, H., Soleymani, M., and Noorbakhsh, E. (2007). "A comparison between statistical and data mining methods for credit scoring in case of limited available data," in The 3rd CRC Credit Scoring Conference. Edinburgh, Scotland, UK: Credit Research Centre.

Santhanam, R. and Hartono, E. (2003). "Issues in linking information technology capability to firm performance," MIS Quarterly,27(1), pp. 125-153.

Shafer, S. M. and Byrd, T. A. (2000). "A framework for measuring the efficiency of organizational investments in information technology using data envelopment analysis," Omega, 28(2), pp. 125-141.

Sircar S., Turnbow J. L., Bordoloi B. (2000). "A framework for assessing the relationship between information technology investments and firm performance," Journal of Management Information Systems, 16(4), pp.69-97.

Sriram, V. and Stump R. (2004). "Information technology investments in purchasing: an empirical investigation of communications, relationship and performance outcomes," Omega, 32(1), pp.41-55.

Stavrou, E. T., Charalambous, C., and Spiliotis, S. (2007). "Human resource management and performance: A neural network analysis," European
Journal of Operational Research, 181(1), pp. 453-467.

Stiroh, K. (2001). "Investing in information technology: productivity payoffs for US industries," Current Issues in Economics and Finance, 7(6), pp. 1-6.

Strassmann, P. A. (1990). The Business Value of Computers: An Executive's Guide., Infomation Economic Press: New Canaan, USA.

Stratopoulos, T. and Dehning, B. (2000). "Does successful investment in information technology solve the productivity paradox?," Information \& management, 38(2), pp. 103-117.

Tang, Z. and Fishwick, P. A. (1993). "Feedforward neural nets as models for time series forecasting," ORSA Journal on Computing, 5(4), pp. 374-385.

Thouin, M.F., Hoffman, J.J. and Ford, E.W. (2009). "IT outsourcing and firm-level performance:a transaction cost perspective," Information \& Management, 46(8), pp. 463-469.

Turban, E. (2001). Information Technology for Management: Making Connections for Strategic Advantage John Wiley \& Sons: Hoboken, New Jersey, USA.

Wahby, M. F. and AL-Suhaibani, S. A. (2002). "Repair and Maintenance Cost Models for Agricultural Equipment in Saudi Arabia," in ASABE Annual Meeting. Sacramento, CA, USA: ASBAE.

Weill, P. (1992). "The relationship between investment in information technology and firm performance: A study of the valve manufacturing sector," Information Systems Research, 3(4), pp. 307-333.

Weill, P., Broadbent, M., and Butler, C. (1996). Exploring how firms view IT infrastructure, Melbourne Business School, the University of Melbourne: Australia. 
The Influence of IT Investment on Business Performance/ Hung. et al.

Weill, P. and Olson, M. H. (1989). "Managing investment in information technology: mini case examples and implications," MIS Quarterly, 13(1), pp. 3-17.

Weiss, S. and Kulikowski, C. (1991). Computer Systems That Learn: Classification And Prediction Methods From Statistics, Neural Nets, Machine Learning And Expert Systems (Machine Learning Series), Morgan Kaufmann: San Mateo, CA, USA.

Whisler, T. L. and Leavitt, H. J. (1958). "Management in the 1980's," Harvard Business Review, 36, pp. 41-48.

Zhang, G. P., Patuwo, B. E., and Hu, M. Y. (2001). "A simulation study of artificial neural networks for nonlinear time-series forecasting," Computers \&

\section{About Authors}

Shin-Yuan Hung is an Information Systems Professor and the Dean of College of Management at National Chung Cheng University in Taiwan. He was a visiting scholar of the MIS Department at the University of Arizona during summer 2007-spring 2008. Dr. Hung received his bachelor degree in Statistics from National Chung Hsing University and his master and doctoral degrees in Information Systems from National Sun Yat-sen University. His current research interests include decision support systems, knowledge management, electronic commerce, and data mining. $\mathrm{He}$ has published papers in Decision Support Systems, Information \& Management, International Journal of Human-Computer Studies, Electronic Commerce Research and Applications, Information Technology \& People, Communications of the AIS, Journal of Global Information Management, Government Information Quarterly, Pacific Asian Journal of Association for Information
Operations Research, 28(4), pp. 381-396.

Zhu, K.and Kraemer K.L. (2002). "e-Commerce Metrics for Net-Enhanced Organizations: Assessing the Value of e-Commerce to Firm Performance in the Manufacturing Sector,"Information Systems Research,13(3), pp. 275-295.

Zuboff, S. (1998). In the age of smart machine: The future of work and power, Heinemann Professional Publishing: Portsmouth, $\mathrm{NH}$, USA.

Zurada, J. and Lonial, S. (2005). "Comparison of the performance of several data mining methods for bad debt recovery in the healthcare industry," Journal of Applied Business Research, 21(2), pp. 37-54.

Systems, among others. Currently, he serves as an Associate Editor of Information \& Management and an Area Editor of Journal of Information Management.

Ya-Han $\mathrm{Hu}$ is currently an Associate Professor of Department of Information Management at National Chung Cheng University, Taiwan. He received a PhD degree in Information Management from National Central University of Taiwan in 2007. His current research interests include data mining and knowledge discovery, decision support systems, and electronic commerce technologies. His research has appeared in Decision Support Systems, Artificial Intelligence in Medicine, Data \& Knowledge Engineering, IEEE Transactions on Systems, Man, and Cybernetics, Journal of Information Science, and Journal of Systems and Software. 
The Influence of IT Investment on Business Performance/Hung. et al.

Chin-S Ou is a Professor in the Department of Accounting and Information Technology, Nation Chung Cheng University. He received his Doctoral degree in Business Administration (Accounting) from the University of Minnesota, USA. His main research areas include Performance Measurement, Evaluation and Management and Managerial Accounting. His research papers have been published at European Journal of Operational Research, Information and Management, International Journal of Operations and Production Management, Journal of Accounting Auditing and Finance, Journal of Engineering and Technology Management, Public Choice, Journal of Management, NTU Management Review, and Others.

Kuanchin Chen is a Professor of Computer Information Systems at Western Michigan University. Dr. Chen's research interests include electronic business, privacy \& security, online behavioral issues (e.g., interactivity, dependency, and tracking/protection), Internet frauds, usability, data mining, business analytics and human computer interactions. $\mathrm{He}$ has published articles in journals and other academic publication outlets, including Decision Support Systems, Information \& Management, IEEE Transactions on Systems, Man, and Cybernetics, Journal of Database Management, Communications of the Association for Information Systems (CAIS), Electronic Commerce Research and Applications, Journal of Global Information Management, DATA BASE for Advances in Information Systems, IEEE Transactions on Education, Decision Sciences Journal of Innovative Education, Internet Research and many others. Dr. Chen has received several research and teaching awards, including department, university and U.S. Congress supported Fulbright awards.
Chun-Chuan Lu received his master degree in information management from National Chung Cheng University in Taiwan. 